\title{
Mechanisms of long noncoding RNA function in development and disease
}

\author{
Sandra U. Schmitz ${ }^{1}$ Phillip Grote ${ }^{2}$ Bernhard G. Herrmann ${ }^{1,3}$
}

Received: 1 February 2016/Revised: 23 February 2016/Accepted: 1 March 2016/Published online: 23 March 2016

(C) The Author(s) 2016. This article is published with open access at Springerlink.com

\begin{abstract}
Since decades it has been known that nonprotein-coding RNAs have important cellular functions. Deep sequencing recently facilitated the discovery of thousands of novel transcripts, now classified as long noncoding RNAs (lncRNAs), in many vertebrate and invertebrate species. LncRNAs are involved in a wide range of cellular mechanisms, from almost all aspects of gene expression to protein translation and stability. Recent findings implicate lncRNAs as key players of cellular differentiation, cell lineage choice, organogenesis and tissue homeostasis. Moreover, IncRNAs are involved in pathological conditions such as cancer and cardiovascular disease, and therefore provide novel biomarkers and pharmaceutical targets. Here we discuss examples illustrating the versatility of lncRNAs in gene control, development and differentiation, as well as in human disease.
\end{abstract}

Keywords LncRNA - Differentiation .

Cardiovascular disease - Cancer - Gene regulation .

Chromatin · Epigenetics - Genome organization

Sandra U. Schmitz

sschmitz@molgen.mpg.de

$\bowtie$ Bernhard G. Herrmann

herrmann@molgen.mpg.de

1 Department of Developmental Genetics, Max Planck Institute for Molecular Genetics, Ihnestr. 63-73, 14195 Berlin, Germany

2 Institute of Cardiovascular Regeneration, Center for Molecular Medicine, Goethe University, Theodor-Stern-Kai 7, 60590 Frankfurt, Germany

3 Institute for Medical Genetics, Campus Benjamin Franklin, Charite-University Medicine Berlin, Hindenburgdamm 30, 12203 Berlin, Germany

\section{Introduction}

It has long been known that several classes of non-proteincoding RNA molecules exert important cellular functions. For instance, ribosomal RNAs (rRNAs) are essential elements of the translation machinery and small nuclear RNAs (snRNAs) are required for splicing of nascent RNA transcripts. Also, various classes of small (around 20-30 nucleotides) noncoding RNAs such as micro (mi)RNAs, small inhibitory (si)RNAs or PIWI interacting (pi)RNAs are well known as gene silencers. With the recent advent of massive parallel sequencing techniques, however, it has been observed that a tremendously high portion, approximately $70 \%$, of the genome is transcribed in various contexts and cell types $[1,2]$. A large proportion of these newly detected RNA transcripts are structurally indistinguishable from protein-coding and processed messenger RNAs (mRNAs). They tend to be expressed at a very low level and have little to no protein-coding potential. This subclass of noncoding transcripts of variable length and function is collectively referred to as long noncoding RNAs (lncRNAs).

A plethora of biological tissues, organs, pathological samples and cultured cells have been analyzed for noncoding RNA expression, and it is clear that these molecules are omnipresent. Apparently, defining noncoding RNA function has proven more challenging than detecting them, as the number of reports showing comprehensive functional data is far smaller than those describing their identification in various contexts. The flexibility of RNA transcripts and their ability to fold into complex 3D-conformations enables them to form specific interactions with proteins. They can interact with RNA or DNA molecules via base pairing, even with double-stranded DNA, and form networks with DNA, protein complexes and RNA 
molecules, illustrating their large potential as an important player with many biological functions. In this review, we will discuss mechanisms of lncRNA functions with a focus on their role in development and disease (Table 1).

\section{Molecular and genetic structure of LncRNAs}

Like mRNAs, IncRNAs are transcribed by Polymerase II, mostly $5^{\prime}$-capped, polyadenylated and spliced, though on average they contain a lower number of exons than mRNAs and their expression level assessed across different tissues is lower [3, 4]. There are various algorithms calculating the coding probability based on the length of a potential open reading frame (ORF), the similarity of such an ORF to known protein-coding genes, frequency of inframe nucleotide hexamers or other empirical sequence features [5]. In general, RNA transcripts containing short $(<100 \mathrm{nt})$ non-conserved ORFs, which have no homology to known peptide sequences and do not match to peptides identified in mass spectrometry screens are considered noncoding [6]. Interestingly, the majority of IncRNAs are associated with ribosomes $[7,8]$, though they do not show the characteristic release of ribosomes [9] or the typical 3-nucleotide phasing corresponding to codons of an ORF $[10,11]$. However, in rare instances, functional oligopeptides have been found to be translated from putative lncRNAs [12-14].

Deep-sequencing experiments revealed many examples of genes producing both protein-coding and noncoding transcripts by alternative splicing. However, so far, only very few reports demonstrate a functional role for both the noncoding RNA(s) and the protein(s) encoded by transcripts derived from the same gene $[15,16]$. It is tempting to speculate that such dual usage of transcripts is more frequent than anticipated.

RNA molecules have the potential to form highly structured macromolecules by folding into double-stranded stems, single-stranded loops and bulges, which again can fold further into three-dimensional structures, allowing for the potential formation of complex shapes. So far, the structure of only a few RNAs has been experimentally determined using a combination of chemical assays, and by determining the accessibility of base-paired or singlestranded RNA by various RNases [17, 18]. However, these methods still have the limitation that they can only reveal the secondary, but not the tertiary (3D) structure. In addition, computational predictions are only beginning to provide reliable results, but program learning from experimental data might improve the predictions and more closely mirror experimental observations. This process is

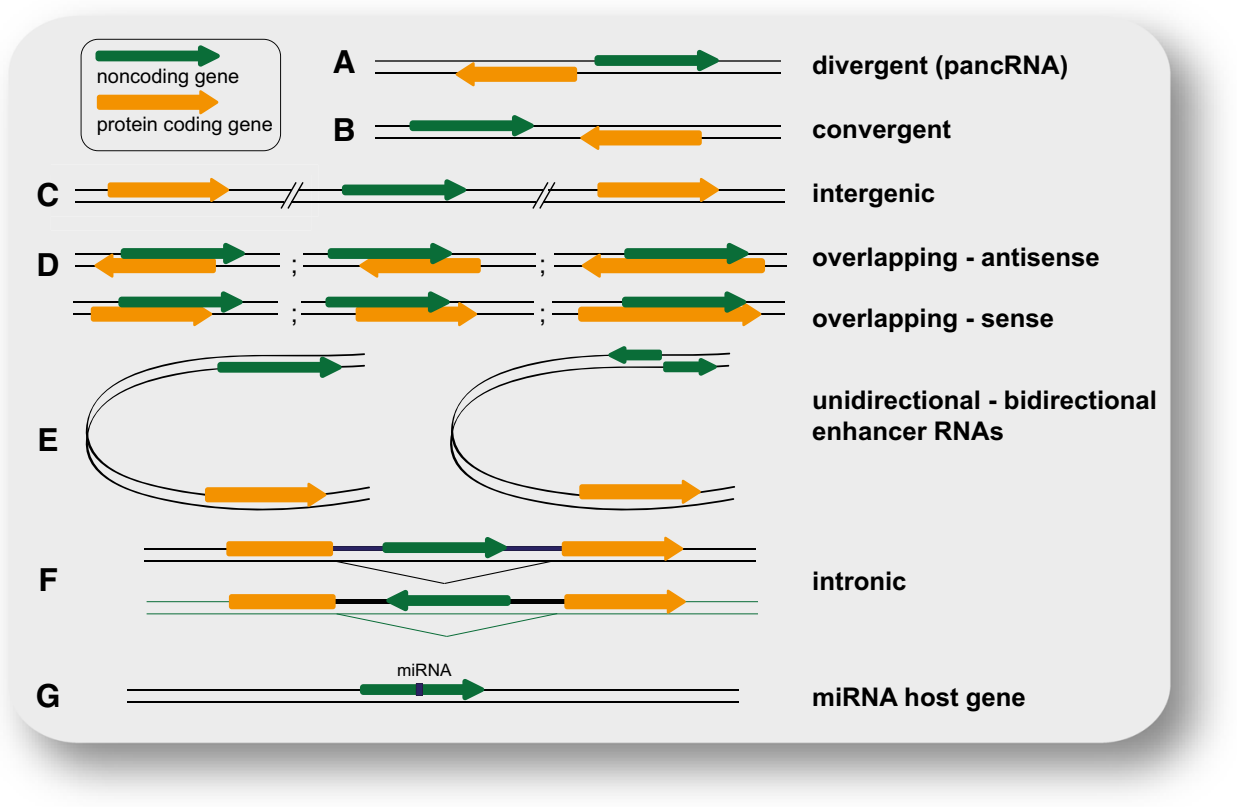

Fig. 1 Classification of lncRNAs according to their position relative to neighboring gene(s). a Divergently transcribed lncRNA originating from the same promoter region as the adjacent (usually protein coding) gene, but from the opposite strand; b convergently transcribed genes encoded on opposite strands and facing each other; c intergenic (or intervening) lncRNA (or lincRNA) located distant from other genes (usually $>10 \mathrm{~kb}$ ); $\mathbf{d}$ examples for various cases of lncRNAs overlapping with other genes on the same or the opposite strand; e enhancer RNAs expressed as uni- or bidirectional transcripts; f LncRNA transcribed from an intron of another gene; g lncRNA hosting a miRNA. Noncoding genes are shown in green, protein-coding genes in orange 
a Eviction of proteins from chromatin
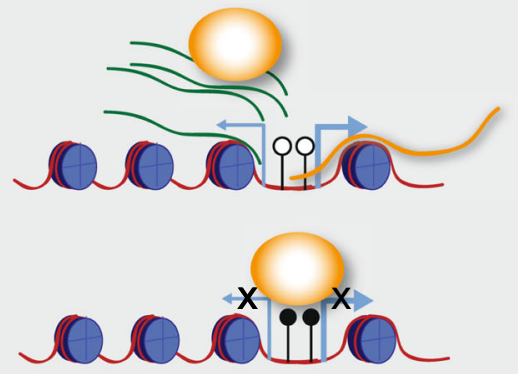

\section{b Stabilizing looping and recruitment} of transcriptional regulators

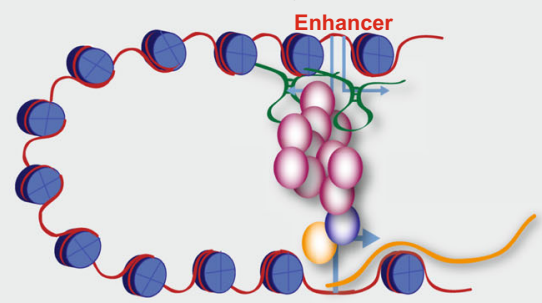

C Counteracting loop formation

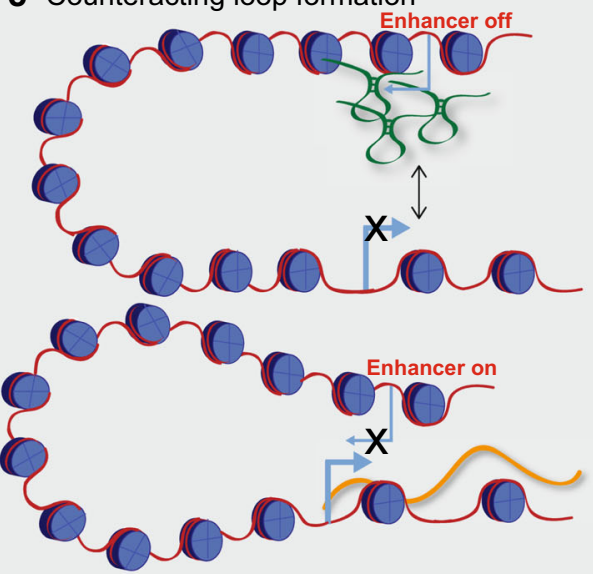

d Recruitment of proteins

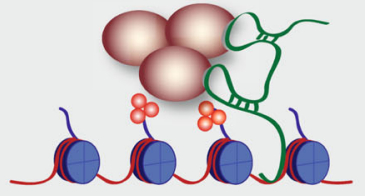

e Scaffolding of proteins

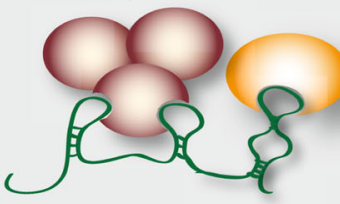

f Sequestering of proteins or miRNAs

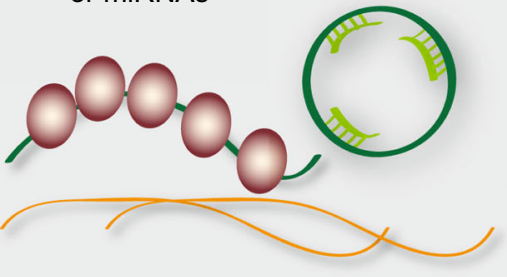

g Alternative splicing

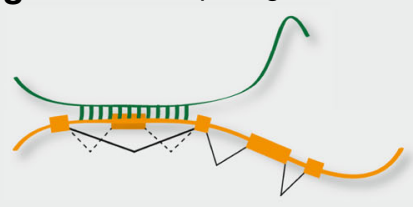

h Stabilizing of mRNAs

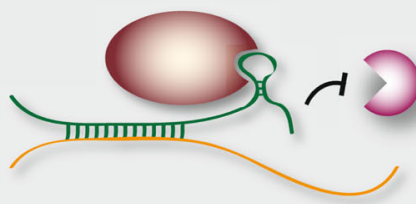

Fig. 2 Schematic representation of cellular mechanisms involving lncRNAs. a LncRNA transcripts evicting proteins from chromatin; here, pancRNAs prevent DNMT from methylating DNA in their promoter region, thereby ensuring mRNA transcription. b LncRNAs recruiting the Mediator complex to an enhancer region, stabilizing loop formation and transcription of the associated gene. c LncRNAs transcribed from an enhancer region interfering with enhancerpromoter contact, thereby inhibiting transcription of the proteincoding gene. d LncRNA recruiting proteins, such as chromatin-

accelerated by recently developed techniques combined with high-throughput sequencing, such as SHAPE-MaP and icSHAPE [19, 20]. modifying complexes to specific target sites in the genome, e.g. via DNA-RNA triplex formation. e LncRNA acting as scaffold linking different proteins required for concerted action. f LncRNA binding and sequestering proteins to prevent or attenuate their action, e.g. binding to mRNAs (left); circRNA sequestering miRNAs to prevent their binding to mRNAs (right). $\mathbf{g}$ Example of a lncRNA changing the splicing pattern by binding to a primary RNA transcript. $\mathbf{h}$ LncRNA stabilizing a mRNA by recruiting proteins such as STAU1, thereby preventing degradation

The similarity between mRNA-encoding and lncRNA genes is furthermore reflected by the chromatin signatures at the genomic regions from where they are transcribed. Their 
Table 1 List of lncRNAs and their main features mentioned in this review

\begin{tabular}{|c|c|c|c|c|c|c|}
\hline Name & $\begin{array}{l}\text { Genomic } \\
\text { category }\end{array}$ & $\begin{array}{l}\text { Neigh-boring } \\
\text { gene }\end{array}$ & $\begin{array}{l}\text { Cellular } \\
\text { localisation }\end{array}$ & Mechanism & $\begin{array}{l}\text { Physiological/pathological } \\
\text { setting }\end{array}$ & References \\
\hline$A I R N$ & $\begin{array}{l}\text { Antisense/ } \\
\text { overlapping }\end{array}$ & $I G F 2 R$ & Nucleus & Transcription & Imprinting & [118] \\
\hline$A N C R(D A N C R)$ & $\begin{array}{l}\text { LincRNA, } \\
\text { miRNA } \\
\text { host gene }\end{array}$ & ERVMER34 & Nucleus & Histone modification & Epidermal differentiation & {$[139,140]$} \\
\hline ANRIL & Antisense & $C D K N 2 B$ & Nucleus & Histone modification & $\begin{array}{l}\text { Different cancer types, } \\
\text { CVD }\end{array}$ & {$[58,59,169]$} \\
\hline BCAR4 & $\begin{array}{r}\text { Divergent } \\
\text { lncRNA }\end{array}$ & RSL1D1 & Nucleus & Histone modification & Breast cancer & {$[82]$} \\
\hline BRAFP1 (Braf-rs1) & Pseudo gene & ZDHHC15 & Cytoplasm & Post transcriptional & DLBCL & {$[158]$} \\
\hline Braveheart (Bvht) & LincRNA & $I L 17 b$ & Nucleus & Histone modification & Cardiac differentiation & [45] \\
\hline$C D R 1$ & CircRNA & $C D R 1$ & Cytoplasm & Post transcriptional & Neuronal tissue & {$[26,27]$} \\
\hline $\begin{array}{l}\text { DACOR1 } \\
\quad(\text { TCONS_00023265) }\end{array}$ & LincRNA & $S M A D 3$ & Nucleus & DNA methylation & Colon cancer & {$[74]$} \\
\hline DEANR1, ALIEN & LincRNA & FOXA2 & Both & Transcription factor & $\begin{array}{l}\text { Endoderm and cardiac } \\
\text { differentiation }\end{array}$ & {$[76,77]$} \\
\hline ecCEBPA & $\begin{array}{l}\text { Upstream } \\
\text { lncRNA }\end{array}$ & $C E B P a$ & Nucleus & DNA methylation & n.d. & {$[64]$} \\
\hline Evf2 (Dlx6os) & $\begin{array}{l}\text { Divergent } \\
\text { lncRNA/ } \\
\text { overlapping }\end{array}$ & $D l x 5 / 6$ & Nucleus & $\begin{array}{l}\text { Chromatin } \\
\text { remodeling }\end{array}$ & Neuronal development & {$[69,70]$} \\
\hline FAL1 & $\begin{array}{l}\text { LincRNA } \\
\quad(2 \mathrm{~kb})\end{array}$ & ECM1 & Nucleus & $\begin{array}{l}\text { Post transcriptional, } \\
\text { histone } \\
\text { modification }\end{array}$ & Ovarian cancer & {$[57]$} \\
\hline Fendrr & $\begin{array}{r}\text { Divergent } \\
\text { lncRNA }\end{array}$ & Foxf1 & Nucleus & Histone modification & Development & {$[47,123]$} \\
\hline FIRRE & LincRNA & RNA5SP514 & Nucleus & $\begin{array}{l}\text { 3D genome } \\
\text { organization }\end{array}$ & $3 \mathrm{D}$ genome structure & [103] \\
\hline Gtl2 (MEG3) & LincRNA & RTL1 & Nucleus & $\begin{array}{l}\text { Histone modification, } \\
\text { DNA methylation }\end{array}$ & Imprinting & {$[55,122,177]$} \\
\hline$H 19$ & LincRNA & $I G F 2 / N C T C 1$ & Nucleus & DNA methylation & $\begin{array}{l}\text { Imprinting, muscle } \\
\text { differentiation }\end{array}$ & {$[116,117]$} \\
\hline HOTAIR & LincRNA & $\begin{array}{l}\text { HOXC11/ } \\
\quad \text { HOXC12 }\end{array}$ & Nucleus & Histone modification & $\begin{array}{l}\text { Different cancer types, } \\
\text { skeletal development }\end{array}$ & {$[42-44,152]$} \\
\hline HOTAIRM1 & $\begin{array}{r}\text { Divergent } \\
\text { lncRNA }\end{array}$ & $\begin{array}{l}\text { HOXA1, } \\
\quad \text { HOXA2 }\end{array}$ & n.d. & n.d. & Myeloid cancer cell lines & [178] \\
\hline Hotdog & $\begin{array}{l}\text { Enhancer } \\
\text { RNA }\end{array}$ & HoxD & Nucleus & Enhancer & Development & [179] \\
\hline HOTTIP & $\begin{array}{r}\text { Divergent } \\
\text { lncRNA }\end{array}$ & HOXА13 & Nucleus & Histone modification & Limb development & {$[62]$} \\
\hline$J p x$ & LincRNA & Xist & Nucleus & Transcription factor & $\begin{array}{l}\mathrm{X} \text {-chromosome } \\
\text { inactivation }\end{array}$ & {$[83,84]$} \\
\hline Lethe & Pseudo gene & Gmebl & Nucleus & Transcription factor & Inflammation & [79] \\
\hline $\begin{array}{l}\text { Linc-HOXA1 } \\
\quad(\text { Linc1547, HAUNT })\end{array}$ & LincRNA & HOXA1 & Nucleus & $\begin{array}{l}\text { Enhancer, histone } \\
\text { modification }\end{array}$ & Development & {$[99,123]$} \\
\hline Linc-P21 & LincRNA & $p 21$ & Nucleus & Transcription factor & Cancer, CVD & {$[123,163,165,166]$} \\
\hline Lnc-DC & LincRNA & HEATR6 & Cytoplasm & Transcription factor & $\begin{array}{l}\text { Dendritic cell } \\
\text { differentiation }\end{array}$ & {$[81]$} \\
\hline LncMyoD & LincRNA & Munc, MyoD1 & Both & Post transcriptional & Muscle differentiation & [180] \\
\hline $\operatorname{lncTCF7}(W S P A R)$ & LincRNA & TCF7 & Nucleus & $\begin{array}{l}\text { Chromatin } \\
\text { remodeling }\end{array}$ & Hepatocellular carcinoma & {$[72]$} \\
\hline LUNARl & $\begin{array}{r}\text { Divergent } \\
\text { lncRNA }\end{array}$ & $\begin{array}{l}\text { PGPEPIL, } \\
\quad I G F I R\end{array}$ & Nucleus & Transcription factor & Acute leukemia & {$[151]$} \\
\hline MALAT1 (NEAT2) & LincRNA & SCVL1 & Nucleus & Post transcriptional & Metastasis & {$[109,110,149]$} \\
\hline
\end{tabular}


Table 1 continued

\begin{tabular}{|c|c|c|c|c|c|c|}
\hline Name & $\begin{array}{l}\text { Genomic } \\
\text { category }\end{array}$ & $\begin{array}{l}\text { Neigh-boring } \\
\text { gene }\end{array}$ & $\begin{array}{l}\text { Cellular } \\
\text { localisation }\end{array}$ & Mechanism & $\begin{array}{l}\text { Physiological/pathological } \\
\text { setting }\end{array}$ & References \\
\hline $\begin{array}{l}\text { MiAT (Gomafu, } \\
\quad \text { RNCR2) }\end{array}$ & LincRNA & $C R Y B A 4$ & Nucleus & Post transcriptional & $\begin{array}{l}\text { Myocardial infarction, } \\
\text { neuronal differentiation, } \\
\text { brain development, } \\
\text { schizophrenia }\end{array}$ & {$[107,108,138,167]$} \\
\hline MIR31HG & $\begin{array}{l}\text { LincRNA, } \\
\text { miRNA } \\
\text { host gene }\end{array}$ & INK4A & Nucleus & Histone modification & Senesence & [161] \\
\hline Myheart (Mhrt) & $\begin{array}{l}\text { Divergent } \\
\text { lncRNA/ } \\
\text { overlapping }\end{array}$ & Myh6/7 & Nucleus & $\begin{array}{l}\text { Chromatin } \\
\text { remodeling }\end{array}$ & Myocardial infarction & {$[68]$} \\
\hline$N B A T-1$ & $\begin{array}{r}\text { Divergent } \\
\text { lncRNA }\end{array}$ & CASC15 & Nucleus & Histone modification & $\begin{array}{l}\text { Neuronal differentiation, } \\
\text { different tumors }\end{array}$ & {$[148,150]$} \\
\hline NEAT1 & LincRNA & FRMD8 & Nucleus & n.d. & $\begin{array}{l}\text { Progesterone } \\
\text { production/corpus } \\
\text { luteum formation }\end{array}$ & {$[124,127]$} \\
\hline NeST (Tmevpg1) & LincRNA & $I F N g$ & Nucleus & Histone modification & Infections & {$[63]$} \\
\hline NKILA & Overlapping & PMEPA1 & Cytoplasm & Transcription factor & Breast cancer & {$[153,154]$} \\
\hline NORAD (LINC00657) & LincRNA & $C N B D 2$ & Cytoplasm & Post transcriptional & Genomic stability & [111] \\
\hline PACER & $\begin{array}{r}\text { Divergent } \\
\text { lncRNA }\end{array}$ & COX2/PTGS2 & Nucleus & Transcription factor & Infection & {$[80]$} \\
\hline pancIL17d & $\begin{array}{r}\text { Divergent } \\
\text { lncRNA }\end{array}$ & $I L 17 b$ & Nucleus & DNA methylation & $\begin{array}{c}\text { Preimplantation } \\
\text { development }\end{array}$ & {$[66]$} \\
\hline PARTICLE & $\begin{array}{r}\text { Divergent } \\
\text { lncRNA }\end{array}$ & $M A T 2 A$ & Both & Histone modification & $\begin{array}{l}\text { Increased in plasma from } \\
\text { patients post-radiation }\end{array}$ & {$[54]$} \\
\hline PCGEM1 & LincRNA & $T M E F 2$ & Nucleus & $\begin{array}{l}\text { Transcription factor, } \\
\text { histone } \\
\text { modification }\end{array}$ & Prostate cancer & {$[101,144,181]$} \\
\hline Pint & $\begin{array}{r}\text { Divergent } \\
\text { lncRNA }\end{array}$ & $2210408 F 21 R i k$ & Nucleus & Histone modification & $\begin{array}{l}\text { Colorectal cancer, } \\
\text { growth/size }\end{array}$ & {$[48,123]$} \\
\hline Pnky & $\begin{array}{r}\text { Divergent } \\
\text { lncRNA }\end{array}$ & Pou $3 f 2$ & Nucleus & Post transcriptional & Neuronal differentiation & {$[105]$} \\
\hline PRNCR1 & LincRNA & CASC19 & Nucleus & $\begin{array}{l}\text { Transcription factor, } \\
\text { histone } \\
\text { modification }\end{array}$ & Prostate cancer & {$[101,181]$} \\
\hline$R M S T$ & LincRNA & NEDDI & Nucleus & Transcription factor & Neuronal differentiation & {$[78,129,133]$} \\
\hline RNCR4 & $\begin{array}{r}\text { Divergent } \\
\text { lncRNA }\end{array}$ & Mirc $35 H G$ & Both & Post transcriptional & Retina development & [136] \\
\hline SChLAP1 & LincRNA & $U B E 2 E 3$ & Nucleus & $\begin{array}{l}\text { Chromatin } \\
\text { remodeling }\end{array}$ & Prostate cancer & [67] \\
\hline TARID & $\begin{array}{r}\text { Divergent } \\
\text { lncRNA }\end{array}$ & TCF 21 & Nucleus & DNA methylation & Different cancer types & {$[65]$} \\
\hline TINCR & LincRNA & $S A F b 2$ & Cytoplasm & Post transcriptional & Epidermal differentiation & {$[141,142]$} \\
\hline$T$ six & $\begin{array}{l}\text { LincRNA/ } \\
\text { antisense }\end{array}$ & Xist & Nucleus & $\begin{array}{l}\text { Transcription factor, } \\
\text { histone } \\
\text { modification, } \\
\text { chromatin } \\
\text { remodeling }\end{array}$ & $\begin{array}{l}\mathrm{X} \text {-chromosome } \\
\text { inactivation }\end{array}$ & [83] \\
\hline $\begin{array}{l}\text { TUNA (megamind, } \\
\text { Linc86023) }\end{array}$ & LincRNA & Tcll & Both & Post transcriptional & Pluripotency, Huntington & {$[33,106]$} \\
\hline Twin of Hotdog & $\begin{array}{l}\text { Enhancer } \\
\text { RNA }\end{array}$ & HoxD & Nucleus & Enhancer & Development & [179] \\
\hline$U C A 1$ & LincRNA & ORIOH1 & Cytoplasm & Post transcriptional & Senesence & [162] \\
\hline Xist & $\begin{array}{l}\text { LincRNA/ } \\
\text { antisense }\end{array}$ & Tsix & Nucleus & $\begin{array}{l}\text { Transcription factor, } \\
\text { histone } \\
\text { modification, } \\
\text { chromatin } \\
\text { remodeling }\end{array}$ & $\begin{array}{l}\mathrm{X} \text {-chromosome } \\
\text { inactivation }\end{array}$ & $\begin{array}{l}{[40,71,120,121,} \\
\quad 182,183]\end{array}$ \\
\hline
\end{tabular}


transcriptional start site is, in most cases, marked by the $\mathrm{H} 3 \mathrm{~K} 4 \mathrm{me} 3$ histone modification and the transcribed region by the H3K36me 3 mark, no matter if the IncRNA originates from its own promoter or from an enhancer. However, these histone marks are less prominent than observed at mRNA coding genes, whereas $\mathrm{H} 3 \mathrm{~K} 4 \mathrm{me} 1$, a characteristic mark of enhancers, tends to be more prominent at genomic regions encoding lncRNAs [2, 21-23]. As expected for transcribed regions, lncRNA promoters correspond with DNaseI hypersensitive sites, which indicates accessible chromatin [24, 25].

So far, the most commonly used categorization of the highly heterogeneous class of lncRNAs is their position in the genome relative to protein-coding genes (Fig. 1). LncRNAs can be intergenic (lincRNAs) or divergently transcribed from the same promoter as a protein-coding gene (pancRNAs). LincRNAs expressed from a promoter (with high $\mathrm{H} 3 \mathrm{~K} 4 \mathrm{me} 3$ to $\mathrm{H} 3 \mathrm{~K} 4 \mathrm{me} 1$ ratio) are classified as promoter-associated lncRNAs (plncRNAs). However, lncRNAs can also be transcribed from enhancers and are then termed eRNAs. They are mostly transcribed in both directions, in contrast to enhancer-associated lncRNAs (elncRNAs), which are unidirectionally transcribed from a promoter with low $\mathrm{H} 3 \mathrm{~K} 4 \mathrm{me} 3$ to $\mathrm{H} 3 \mathrm{~K} 4 \mathrm{me} 1$ ratio [23]. Transcription of IncRNAs can also originate from within introns, or overlap with other transcripts in sense or antisense orientation [3]. Some lncRNAs are generated by backsplicing from introns of mRNAs or other lncRNAs and are thus circular (circRNAs) [26, 27].

Genome-wide sequencing of RNA species isolated from cytosolic or nuclear fractions of cells has shown that the majority of lncRNAs tend to be localized in the nucleus or are associated with chromatin, while a considerable fraction localizes to the cytoplasm [3, 28, 29]. The subcellular localization is a good indication of the putative function of a lncRNA, since in contrast to protein-coding mRNAs, lncRNAs can already function while transcription is occurring. In fact, many nuclear and, in particular, chromatinretained lncRNAs co-regulate transcription and/or chromatin structure at or close to their site of transcription, i.e. in cis.

\section{Conservation and evolutionary aspects of LncRNA}

The genomic sequences of IncRNAs are, in general, less conserved than exons, but more than introns of proteincoding genes, pointing towards a rapid evolution with moderate constraints $[21,30]$. In contrast to the actual sequence, splice sites of lncRNAs have been found to be more stable during evolution [31, 32]. Despite poor RNA sequence conservation, IncRNAs have frequently been identified across species in syntenic genomic regions [33, 34]. It is therefore quite likely that evolutionary conservation of lncRNAs is embodied by a conserved 3D structure, although this is difficult to assess with current methods. A further layer of conservation is functional conservation between lncRNAs playing equivalent roles in particular biological settings [35].

A different explanation for low conservation of lncRNAs is the increasing number of such transcripts in increasingly complex species. This finding, in combination with the observed highly tissue-specific expression of many lncRNAs, suggests that lncRNAs might be key molecules promoting species-specific features and organ complexity [36-38]. Thus, IncRNAs very likely have played important roles in the evolution of complex organisms.

\section{LncRNAs regulate gene and genome activity}

The best-described function for lncRNAs in the nucleus is their role in regulating gene and genome activity on various levels (Fig. 2a-e). Many possible mechanisms by which lncRNAs influence chromatin modifications and chromatin structure, and thereby influence transcription or other chromatin-related functions by epigenetic mechanisms have been investigated. In the following section we will address different levels of gene and genome regulation separately.

\section{Histone modifications regulated by LncRNAs}

Prominent examples of histone-modifying complexes interacting with lncRNAs are the two polycomb repressive complexes, PRC1 and, in particular PRC2, which mediates methylation of lysine 27 on histone 3 (H3K27me), a histone mark associated with repressed or poised genetic loci. The first report of an interaction of PRC2 with a noncoding RNA came from studies on X-chromosome inactivation in mammals, which involves $X$-inactive specific transcript (Xist), a lncRNA that is highly expressed from the inactive $\mathrm{X}$-chromosomes in females (Xi) and recruits PRC2 to the $\mathrm{Xi}$ to silence gene expression [39-41].

Another prominent example is Hotair, a conserved lncRNA that is transcribed from within the HoxC gene cluster. Hotair was shown to play a repressive role at the HoxD locus by interacting with PRC2. In addition, Hotair also interacts with the histone H3K4me1/2 demethylase LSD1 (KDM1), which removes a histone mark of active chromatin and thus reinforces the establishment of a repressive chromatin environment on target loci [42] (Fig. 2d, e). Targeted inactivation of Hotair in mice leads to de-repression of imprinted genes and of HoxD genes, which lose H3K27methylation and gain H3K4-methylation marks, as expected from loss of the enzymatic activity of PRC2 and LSD1 at these loci. Furthermore, Hotair knockout mice show skeletal homeotic transformation phenotypes, which are typical for mutations affecting Polycomb mediated repression [43]. Interestingly, mice lacking most of the HoxC cluster 
including Hotair do not display these phenotypes, suggesting a complex interplay of multiple genomic regions in regulating HoxC cluster gene expression [44].

Braveheart (Bvht) is a lncRNA that is activated during early cardiac differentiation and acts upstream of MESP1, a basic Helix-loop-helix transcription factor involved in early heart development. Bvht also exerts its function via an interaction with PRC2 [45]. The lncRNA Fetal-lethal developmental regulatory RNA (Fendrr; or Foxfl adjacent noncoding developmental regulatory RNA) is likewise involved in cardiac development and heart function and interacts with PRC2. Fendrr also interacts with WDR5, which is well known for its presence in the MLL complexes that mediate $\mathrm{H} 3 \mathrm{~K} 4$ methylation, a mark that is thought to oppose H3K27me. Fendrr might play a role at poised genes, or is involved in tuning the balance of active and repressive marks at its target gene promoters, thus adjusting the correct expression level of its targets [46, 47]. These examples are only a small selection and many more lncRNAs seem to function in concert with the PRC2 complex; for more examples, see [48-52].

An intriguing mechanism as to how lncRNAs might recruit their protein interaction partners to specific genomic loci is DNA-RNA triplex formation [53], which has been proposed for several lncRNAs forming a complex with PRC2 [46, 54, 55] (Fig. 2d). In this manner, IncRNAs might direct chromatin or transcriptional modulators to specific genomic sites. This could explain, to some extent, the site-specific action of chromatin-modifying complexes, which do not themselves bind to DNA in a sequence specific manner [38, 56].

An example of a lncRNA interacting with the PRC1 complex is Focally amplified lncRNA on Chromosome 1 (FAL1). The interaction of FAL1 with BMI1, an essential subunit of PRC1, regulates its protein stability [57]. The knockdown of $F A L 1$ in an ovarian cancer cell line led to gene expression changes, slower cell cycle progression and induction of senescence, similar to the effects of the BMII knockdown. This latter phenotype could be partially rescued by knockdown of the senescence-promoting factor $C D K N 1 A$ (p21). Additional ChIP data suggested that BMI1 binds to the promoter of $C D K N 1 A$ and, together with $F A L 1$, suppresses the expression of this target and of many other genes.

Whereas FAL1 acts in trans on PRC1, ANRIL, a lncRNA transcribed from the $I N K 4 B-A R F-I N K 4 A$ tumor suppressor locus, acts in cis. The ANRIL transcript was discovered in a family with inherited melanoma-neural system tumors and assumed to play a role in tumorigenesis [58]. ANRIL recruits CBX7 (a PRC1 component) via a POLII-dependent mechanism to its locus in order to repress the neighboring INK4B$A R F-I N K 4 A$ genes, antagonize cellular senescence and indirectly promote cell cycle activity $[58,59]$.

The repressive $\mathrm{H} 3 \mathrm{~K} 27$-methylation, catalyzed by EZH2 in the PRC2 complex, is opposed by MLL complexes, which mediate methylation of $\mathrm{H} 3 \mathrm{~K} 4 \mathrm{me} 2 / 3$, a mark associated with loci that are actively transcribed or primed for activation. WDR5 is an integral part of all MLL complexes, but also interacts with several other protein complexes [60]. WDR5 has been found to interact with more than 200 lncRNAs in mouse embryonic stem cells (mESCs) [61]. These interactions are important for WDR5 binding to chromatin since a point mutant that cannot bind RNA also fails to stably associate with chromatin. More specifically, two lncRNAs, HOTTIP and NeST have been described to recruit WDR5 to their neighboring genes and thus enhance their transcription $[62,63]$.

\section{LncRNAs modulate DNA methylation}

Whereas many lncRNAs associating with Polycomb complexes act by promoting PRC occupancy at genomic target sites, lncRNAs described in the context of DNA methylation have mostly been found to oppose this epigenetic mark. Frequently, transcription of noncoding RNAs, which interact with DNMTs, keeps a locus free of DNA methylation [54, 64-66] (Fig. 2a). Initially, it was observed that knockdown of extracoding CEBPA (ecCEBPA), a transcript starting upstream of the $C E B P A$ gene, leads to down-regulation of $C E B P A$ and increased DNA methylation of the locus. A subsequent global analysis of all lncRNAs bound to DNMT1 [64] revealed that loci whose RNA products interact with DNMT1 show lower levels of DNA methylation than other loci. A similar observation was made in oocytes and two-cell stage embryos [66], in which the down-regulation of several divergently transcribed promoter-associated ncRNA (pancRNA) led to lower expression of the adjacent protein-coding gene and higher DNA methylation. In the case of one particular gene, $I L 17 b$, the pancRNA knockdown resulted in cell death of the developing blastocyst. Supplementing the embryos with IL17b protein rescued the phenotype.

In the case of Tcf 21 antisense RNA reducing DNA methylation (TARID), keeping the protein-coding gene (Tcf21) on the opposite DNA strand free of DNA methylation required GADD45A and the TET proteins [65] pointing towards a mechanism involving active DNA demethylation.

\section{LncRNAs regulate chromatin remodeling}

In addition to interaction with enzymatic complexes, which covalently modify chromatin, IncRNAs have also been shown to control chromatin remodeling complexes that can alter the nucleosome spacing in an energy dependent manner. In human prostate cancer, gene expression analyses showed that SWI/SNF and the IncRNA SChLAPI have opposing roles. SChlAPl interacts with the SNF5 subunit of the chromatin remodeling complex SWI/SNF, 
and globally inhibits binding of SWI/SNF to chromatin, subsequently leading to genome-wide de-repression of gene activity [67]. Similarly, the lncRNA Myheart (Mhrt), a lncRNA transcribed divergently to Myh6 and overlapping with $M y h 7$ in antisense direction, binds to BRG1, the ATPase subunit of the SWI/SNF complex, and excludes it from the $M y h 6 / 7$ locus, thus preventing chromatin remodeling [68]. BRG1, in turn, down-regulates Mhrt. Cardiac stress leads to upregulation of BRG1 to a level allowing it to overcome the repulsion of the SWI/SNF complex from chromatin by Mhrt and to bind to the Myh6 locus.

The Evf2 lncRNA, transcribed from the genomic region between $D l x 5$ and $D l x 6$, promotes SWI/SNF binding to the enhancers of these genes. However, Evf2 inhibits the remodeling activity of SWI/SNF and thus interferes with upregulation of $D l x 5 / D l x 6$. Accordingly, in Evf2 mutant mice, Dlx 6 and, to a lesser extent, Dlx 5 are upregulated $[69,70]$. In a more recent study, it was observed that the binding of Evf2 to BRG1 can be out-competed by other RNAs of similar length and results in reduced remodeling activity, suggesting that the binding of lncRNAs to the SWI/SNF complex is promiscuous. Xist, on the other hand, binds to components of the SWI/SNF complex, but excludes the complex from the $\mathrm{Xi}$, rather than recruiting it [71]. The SWI/SNF complex can also be recruited by lncRNAs and mediate gene activation, as has been found in hepatocellular carcinoma cancer stem cells. A lncRNA, IncTCF7 or WNT signaling pathway activating non-coding RNA (WSPAR), transcribed $200 \mathrm{~kb}$ upstream of TCF7, can recruit SWI/SNF to the TCF7 promoter and thus activate TCF7 expression and WNT signaling [72].

\section{Is the observed binding of numerous IncRNAs to chromatin modifiers specific or promiscuous?}

The specificity of lncRNA interactions with chromatinmodifying complexes has been questioned. For instance, a large number of lncRNAs have been shown to co-purify with PRC2, possibly suggesting non-specific binding [50, $52,73]$. Similarly, $15 \%$ of all $\operatorname{lncRNAs}$ present in a particular cellular context were shown to be bound by DNMT1 $[64,74]$. Likewise, WDR5 binds to more than a thousand RNAs in mESCs, of which $20 \%$ are lncRNAs [61]. This issue of promiscuity was assessed exemplarily for PRC2 in a systematic biochemical study [75], where the authors demonstrate that PRC2 binds RNA in a promiscuous manner, but has remarkably higher affinity for specific lncRNAs than for e.g. bacterial mRNA. Furthermore, they provide evidence that the binding strength correlates with the length of the RNA. Though these studies were performed in vitro at non-physiological conditions, they suggest that the chromatin-modifying complexes can sufficiently differentiate between specific and non-specific interactors. Moreover, since most lncRNA transcripts are expressed at few copies per cell, it is likely that the number of PCR2 molecules per cell is in excess to the number of lncRNA transcripts, which contain a high affinity site for PRC2. Overall, it is not unexpected that a chromatin-modifying complex acting at numerous genomic loci binds many different individual lncRNAs, which stabilize it or recruit it to distinct genomic loci.

\section{Interactions of IncRNAs with transcription factors}

Besides chromatin modifiers, transcription factors have also been found to interact with lncRNAs. The lncRNA definitive endoderm-associated lncRNAl (DEANRI) (also known as $A L I E N$ ), for instance, is transcribed downstream of FOXA2 and is highly induced during differentiation of ESCs towards definitive endoderm [76, 77]. Knockdown of DEANRI inhibits endodermal differentiation due to the reduction of FOXA2 expression. This interpretation is strongly supported by the fact that endoderm differentiation is rescued in DEANRI knockdown cells upon forced FOXA2 expression. Mechanistically, DEANR1 was proposed to interact with $\mathrm{SMAD} 2 / 3$ and to recruit it to the FOXA2 promoter.

The lncRNA rhabdomyosarcoma associated transcript (RMST) is required for neuronal differentiation by mediating binding of the transcription factor SOX2 to approximately half of its binding sites [78]. Certain lncRNAs have been linked in different ways to transcription factors of the NF- $\kappa \mathrm{B}$ pathway. Lethe (after the 'river of forgetfulness' in Greek mythology) interacts with RelA and prevents it from binding to DNA [79]. p50-associated cyclooxygenase-2 (COX-2) extragenic RNA (PACER), on the other hand, sequesters p50, which forms homodimers and is repressive at high concentration, thereby lowering its concentration and allowing it to form activating heterodimers with p65 [80]. Another lncRNA, lnc dendritic cells (lnc-DC) binds to the transcription factor STAT3 in the cytoplasm and prevents its dephosphorylation by SHP1, thereby activating STAT3 and thus dendritic cell differentiation [81].

An elaborate mechanism linking transcription factor binding and chromatin modifications has been found for breast cancer anti-estrogen resistance 4 (BCAR4). This IncRNA binds to the SMAD nuclear interacting protein 1 (SNIP1) and a phosphatase (PNUTS) involved in RNA polymerase II regulation. In response to cytokine stimulation, BCAR4 lifts the inhibitory effect of SNIP1 on p300, a histone acetyl transferase and transcriptional activator. Acetylated histones are necessary for BCAR4 mediated recruitment of PNUTS, which in turn leads to active polymerase II at GLI2 controlled genes [82].

Also CTCF, a protein with the dual function of a transcriptional regulator and a boundary factor, has been shown 
to interact with numerous noncoding RNAs [83]. An example is the interplay between CTCF and the lncRNAs Jpx, Tsix and Xite, which is important for X-chromosome inactivation [83, 84]. Prior to inactivation, Tsix and Xite recruit $\mathrm{CTCF}$ in cis to the $\mathrm{X}$-inactivation center promoting homologous X-chromosome pairing at the Xic [83]. During $\mathrm{X}$-chromosome inactivation, Jpx evicts CTCF in trans from the Xist locus and thereby prevents promoter blockage by CTCF [83]. These examples illustrate the dynamic interaction between IncRNAs and transcription factors in regulating chromatin-mediated cellular functions.

\section{Regulation of genome organization by looping of enhancers}

Previously, transcripts found at enhancers had been interpreted as byproducts of transcription from promoters contacted by enhancers. Now, it is well established that RNA transcripts produced at active enhancers are functionally important [85-87]. An example of enhancer-linked transcripts, already identified two decades ago, has been described for the locus control region (LCR) of the $\beta$-globin cluster [88, 89]. To date, numerous studies have assigned functions to enhancer-associated RNAs [90] (Fig. 2b). There are different classes of RNAs observed at enhancers. The classical enhancer RNAs (eRNAs) are derived from bidirectional transcription, are unspliced and rather short transcripts [85, 91]. Additionally, there are also unidirectional, often spliced and processed transcripts, which are indistinguishable from canonical lncRNAs, but happen to be transcribed from an enhancer [23, 92]. These transcripts often function in cis. Finally, there are lncRNAs with enhancer-like functions (also called ncRNA-a) [93]. Whether this classification reflects different functional classes of RNAs remains to be investigated.

In general, eRNAs are co-regulated with their neighboring gene(s) [91] and presumed to be important for gene expression, possibly by supporting cohesin binding [94]. However, experimental support for the latter is rather mild. While eRNAs in some studies were shown to stabilize chromosome loops [94, 95], they appeared to be dispensable for promoter-enhancer contact in others, raising doubts about the role of eRNAs in chromosome looping [96, 97].

LncRNAs transcribed from enhancer regions can also have inhibitory effects on their target gene. The promoter deletion of the lncRNA Haunt (also known as linc-Hoxal), for instance, has been shown to lead to upregulation of several genes of the neighboring HoxA gene cluster. However, larger deletions in the Haunt locus impair HoxA expression [98], demonstrating that the genomic locus can have opposing functions to the RNA product encoded by it. The repressive effect of Haunt was furthermore observed at the single cell level confirming that the expression of HoxAl and Haunt are anti-correlated [99].

A similar mechanism was found for Playrr (D030025E07Rik), a lncRNA encoded upstream of the homeodomain transcription factor Pitx2 [100]. Pitx2 expression is constrained to the left side of the gut dorsal mesentery, whereas expression of Playrr is detected on the right, but spreads to both sides in Pitx2 deletion mutants. A CRISPR/Cas9 generated mutation resulting in Playrr RNA decay caused upregulation of Pitx2 expression [100]. Both experiments reveal a mutual inhibitory interaction between Pitx2 and Playrr. An enhancer involved in Pitx2 regulation in the gut overlaps the TSS of Playrr. In the cells on the left-hand side, where Pitx 2 is expressed, the Pitx2 locus was found to be in closer proximity to the Playrr locus than in cells on the right side and to cause down-regulation of Playrr by an unknown mechanism. In cells on the right, on the other hand, Playrr RNA is thought to cause a separation of the Pitx2 locus from the enhancer at the Playrr locus suggesting that Playrr expression interferes with the looping of the Pitx2 promoter to its enhancer at the Playrr locus and thus with Pitx2 gene activation (Fig. 2c).

Furthermore, the 1ncRNAs PRNCRI and PCGEMI promote enhancer-promoter looping in prostate cancer cells [101]. Other lncRNAs have been suggested to assist chromosome conformation more globally. A particular situation can be observed at the inactive X-chromosome (Xi). The 3D-structure of $\mathrm{Xi}$ is dependent on Xist, supposedly because Xist excludes cohesin binding from $\mathrm{Xi}$ [71]. Deletion of Xist led to loss of the compact chromosome structure of the $\mathrm{Xi}$ and reorganization into chromosome domains as they are found on the active X-chromosome. Recently, another IncRNA, functional intergenic repeating RNA element (Firre), which escapes $\mathrm{X}$-chromosome inactivation was suggested to stabilize the perinucleolar location of the Xi [102]. Additionally, Firre was proposed to mediate focal trans-chromosomal contacts [103]. This finding was questioned by a different study, which reported a dispersed nuclear distribution of Firre and a role in the control of factors involved in RNA processing [104]. These examples show that lncRNAs can play important roles in controlling local intra- and interchromosomal genomic structure and interactions.

\section{Regulation at the posttranscriptional level}

LncRNAs primarily found in the cytosol are thought to be involved in gene regulation on the posttranscriptional level (Fig. 2e-h). Accordingly, several lncRNAs have been shown to influence splicing patterns of either specific genes or globally by interacting with splicing factors. The lncRNA Pnky (divergent to Pou3fl) binds to the splicing 
factor PTBP1 and thereby regulates the splicing patterns of a subset of genes involved in neurogenesis [105]. Whether TUNA (megamind), which interacts with PTBP1 as well, functions via the same mechanism remains to be investigated [33, 106]. In addition, myocardial infarction associated transcript (MIAT) has been found to influence splicing in different systems. In embryonic neurogenesis, $M I A T$ is involved in controlling the splicing pattern of $W n t 7 b$ [107]. In iPS cells and mouse primary neurons, MIAT binds to splicing factors, and in post-mortem brains of schizophrenia patients, it was found to be down-regulated, suggesting that it might contribute to this pathological phenotype [108]. MALAT1, a highly expressed lncRNA enriched in nuclear speckles, has been suggested to be a general component of the splicing machinery [109]. However, this view has been challenged since the MALAT1 knockout did not show disintegration of splicing speckles [110]. A very specific role in the cytoplasm was found for the lncRNA non-coding RNA activated by DNA damage (NORAD) [111]. NORAD sequesters PUMILIO proteins and thereby promotes genomic stability (Fig. 2f). Ablation of NORAD leads to hyperactivity of PUMILIO causing chromosome instability and aneuploidy due to repression of PUMILIO target mRNAs that function in DNA replication, mitosis and DNA damage repair.

The most recently described class of lncRNAs that came into focus are the circRNAs. Due to their circular structure, they are resistant to degradation by exonucleases and are therefore thought to be highly stable within a cell. The brain specific circRNA CDRlas was shown to act as a sponge for the miRNA let-7 [26, 27] (Fig. 2f). Accordingly, overexpression of CDRlas in zebrafish caused impaired midbrain development, similarly to the effect of a let-7 inhibitor. It was also shown that small polypeptides can be derived from some circRNAs, extending the functional repertoire of these stable RNA molecules [112]. Most likely, circRNAs do not only interact with other transcripts, but also with proteins and thus may function in a wide range of different processes.

\section{Functions of IncRNAs in development and differentiation}

In the following section, we will focus on the physiological effects of lncRNAs in the organism, during embryonic development and in in vitro differentiation systems. There are still few known examples of IncRNAs shown to play important roles in vivo, and thus we will revisit some of the lncRNAs already mentioned above.

Maternal transcripts present in oocytes and zygotes contribute to early differentiation processes. In a single-cell sequencing study examining oocytes, zygotes and cells from the first cell divisions of the early mouse embryo, lncRNA transcripts were found at all stages examined [113]. One subclass of IncRNAs, the pancRNAs, was compared between murine two-cell embryos and oocytes [66]. A subset of pancRNAs found to be expressed in twocell embryos but not in oocytes was found to be important for counteracting DNA methylation at the adjacent promoters thereby ensuring expression of the neighboring gene.

The mechanisms first found to be linked to lncRNAs were imprinting and X-chromosome inactivation. Accordingly, the first lncRNA that was genetically targeted and deleted was H19, an imprinted gene that was already suspected to be a lncRNA 25 years ago [114]. H19 is exclusively expressed from the maternal allele and is inhibitory for the adjacent gene, Insulin-like growth factor 2 (Igf2) [114-116]. An H19 deletion on the maternally inherited chromosome led to an increase in Igf2 expression and thus to increased bodyweight. This phenotype could be rescued by deletion of one $I g f 2$ allele. $H 19$ knockout mice are viable and fertile [116], but have reduced muscle regeneration capacities due to loss of two miRNAs encoded within the $H 19$ transcript [117]. The imprinted $I g f 2 r$ gene is silenced by the lncRNA Airn, which is transcribed from the opposite strand, overlapping the 5-prime region of $I g f 2 r$. Here, silencing is not achieved by the IncRNA transcripts as such, but by transcription through the Igf $2 r$ promoter, which interferes with RNA PolII recruitment [118]. Several further IncRNAs with a well-established role in imprinting have been reported. For details we would like to refer to a recent review [119].

Insight into the developmental function of Xist was obtained two decades ago when Xist knockout mice were generated and analyzed [120, 121]. Male mice lacking Xist are unaffected, whereas females die during the first half of gestation. Interestingly, knockout females with a single $\mathrm{X}$-chromosome (XO) lacking Xist are healthy, strongly suggesting that it is not the lack of Xist, but the failure to adjust the $\mathrm{X}$-chromosome gene dosage that causes embryonic lethality.

In a more recent example, the deletion of another imprinted lncRNA gene in the mouse, Gtl2 (Meg3, maternally expressed 3), showed clear cis-acting effects on neighboring genes resulting in perinatal lethality [122].

Many other mouse models in which lncRNAs have been removed by deletion of genomic fragments did not show overt phenotypes, but after detailed analyses, some specific defects have been observed [110, 123-126]. For instance, deletion of NEATI resulted in viable and fertile mice, however, knockout females showed about $50 \%$ reduced fertility due to reduced progesterone production and corpus luteum formation [127]. Ovary transplantation or progesterone administration rescued offspring rates, confirming 
the cause of the phenotype, though the molecular mechanism remains to be determined.

Fendrr is one of few rare examples of lncRNAs demonstrated to play an essential role in organ development and embryo survival. Fendrr, which is divergently transcribed from the Foxfl promoter, was analyzed by two different strategies $[47,123]$. In one study, the insertion of a transcriptional stop cassette replacing the first exon of Fendrr leaving most of the genomic context undisturbed resulted in impaired heart function, omphalocele (defects in body wall development), and embryonic death [47]. Fendrr interacts with chromatin-modifying complexes and with DNA, possibly through triplex formation, and thereby changes the chromatin landscape of specific target promoters in trans, in particular those of mesodermal transcription factors [46]. A BAC-transgene expressing a single dose of Fendrr rescued the developmental defects caused by the loss of Fendrr, strongly suggesting that the observed phenotype is caused by lack of Fendrr RNA, and not by disruption of genomic sites or promoter elements of the adjacent Foxfl gene. This conclusion was supported by a different knockout strategy, in which the first exon was left intact and which resulted in perinatal death [123]. In the early embryo, Fendrr is only transiently expressed in nascent lateral mesoderm [47]. However, later during development it is expressed in the lungs, a derivate of endoderm and lateral mesoderm, where it again might play an essential role [123, 128].

More lncRNAs involved in mesoderm and endoderm development have been reported. For instance DEANRI (also known as ALIEN) is expressed downstream of the endoderm master regulator FOXA2 [76, 77]. DEANR1 depletion results in reduced expression of FOXA2 and accordingly to reduced differentiation of hESCs towards definitive endoderm. Interestingly, this defect can be rescued by restoring normal levels of FOXA2 expression, suggesting that DEANRI functions mainly in cis. Another study described the same lncRNA, here called ALIEN, in cardiovascular progenitor cells in mouse and zebrafish. Depletion of ALIEN interfered with cardiac development, although the functional mechanism remains to be investigated further. DEANRI was described to be localized in the nucleus, whereas ALIEN was seen in the perinuclear space and in the cytoplasm, even though both were analyzed in differentiating human stem cells. The discrepancy between the two studies might be a consequence of modifications in the differentiation method [76, 77].

Also, the transcription factor Pitx2, which is essential for the development of many different organs, especially during the establishment of left-right asymmetry, is regulated by a lncRNA in the embryonic gut [100]. In this case, the lncRNA Playrr is transcribed from a distant known enhancer region. The expression patterns of Pitx2 and
Playrr are negatively correlated due to interference of Playrr with Pitx2 activation (for details see above).

LncRNAs expressed during neuronal and brain development have attracted particular attention. As described earlier, many lncRNAs are highly specifically expressed in distinct cell types, as illustratively shown in a targeted LacZ reporter screen [37] and in expression screens [36, $107,129,130]$. A number of lncRNAs located close to the PouIII genes Pou $3 f 3$ and Pou3f2 (Brnl and Brn2) encoding important neuronal transcription factors, were also found to play roles in neuronal development [37, 105, 123, 131]. The 1ncRNA Dali (or Dalir) (DNMT1-Associated Long Intergenic RNA) is transcribed $50 \mathrm{~kb}$ downstream of Pou3f3. The depletion of Dali leads to a reduction of Pou $3 f 3$ expression and to impaired neuronal differentiation [131]. Gene expression analysis upon knockdown and genome-wide localization (CHART) revealed POU3F3 dependent and independent targets of Dali. Furthermore, Dali physically interacts not only with various chromatin modifiers, but also with POU3F3 itself suggesting a multilayered association between Dali and POU3F3. The replacement of Pantrl (POU domain, class 3, transcription factor 3 adjacent noncoding transcript), which is divergently transcribed to Pou $3 f 3$, by insertion of the lacZ gene did not influence Pou3f3 transcription itself, but modulated other Pou $3 f$ transcription factors in trans [37]. Pantr2 (or Linc-Brn1b), expressed convergent with Pou3f3, did not have this effect on Pou $3 f$ factors, and upon deletion led to fewer intermediate progenitors in the developing cortex. Thus, each of these three different lncRNAs, which are all transcribed near the Pou3f3 locus, affect neuronal development yet through distinct mechanisms.

Furthermore, another IncRNA located in a region important for neural development is Evf2 in the $D l \times 5 / 6$ locus [69]. Evf2 was targeted by inserting a polyadenylation signal close to the promoter without deleting genomic DNA. Evf $2^{-l-}$ embryos have less GABAergic neurons than wild type controls. This mutant effect could be rescued by in utero electroporation of $E v f 2$ RNA, confirming that the phenotype is indeed dependent on this lncRNA.

RMST, also termed non-coding rhabdomyosarcoma (NCRMS) in humans, is a noncoding transcript expressed in rhabdomyosarcomas [132] and in developing dopaminergic neurons during murine development [133]. RMST is induced during neuronal differentiation of hESCs, and its depletion interferes with neuronal differentiation via its binding partner SOX2 (see above) [78, 107, 129]. Interestingly, RMST was found associated with obesity in a GWAS study, possibly pointing to a role of RMST in a neuronal regulatory network influencing energy balance [134].

Two more lncRNAs involved in nervous system development are the retinal noncoding RNA2 and 4 (RNCR2 and 
RNCR4). They were first found to be expressed in the developing retina and later also assigned a functional role in this process [135]. RNCR4 is part of a network including the RNA helicase DDX3X and the miR-183/96/182 that is essential for retinal architecture [136]. RNCR2, also known as MIAT or Gomafu, interferes with retinal cell differentiation when overexpressed or depleted [135, 137]. Furthermore MIAT is expressed earlier in the developing brain, where it localizes to the nuclear matrix [138]. Purifying distinct subpopulations of the developing brain at E14.5 revealed that MIAT is highly abundant in differentiating progenitors, where it is involved in corticogenesis by regulating the splicing pattern of Wnt7b [107] (Fig. 2g).

Another ectodermal derivative, the developing epidermis, has also been shown to be regulated by lncRNAs. During epidermal differentiation and maintenance, the nuclear lncRNA ANCR (anti-differentiation ncRNA) is essential for maintaining the proliferating progenitor pool by repressing differentiation factors, amongst them the transcription factors MAF and MAFB, probably in a PRC2 linked manner [139-141]. Depletion of ANCR leads to differentiation and loss of progenitor cells. Its differentiation promoting counterpart is a cytosolic IncRNA, terminal differentiation induced ncNRA (TINCR) that interacts with STAU1 and as a protein-RNA complex stabilizes mRNAs of pro-differentiation genes including $M A F$ and $M A F B$ [141, 142] (Fig. 2h). Ectopic expression of MAF:MAFB in TINCR depleted cells restored the expression of the differentiation gene signature showing that TINCR is crucial for ensuring appropriate protein levels in particular of MAF and MAFB.

\section{Functions of IncRNAs in pathological settings}

LncRNAs as a "new" class of molecules have also attracted attention in pathological settings. Here, we will highlight two very prominent areas, cancer and cardiovascular disease.

\section{Cancer}

Approximately one third of publications currently listed in PubMed linked with the keyword "IncRNA" also contain the keyword "cancer". Even before the era of next generation sequencing, a few studies found IncRNAs to be dysregulated in tumors [35, 143, 144]. To date, numerous primary tumor samples, metastatic biopsies, the adjacent normal tissue and cancer cell lines have been profiled for their RNA expression and the results recapitulate the high degree of specificity found for noncoding RNAs in normal tissue compared to protein-coding genes [25, 67, 145-147]. Clustering of lncRNA expression patterns identifies subclasses of tumor types with high significance, opening the possibility to define tumor subtypes with a high chance to respond to targeted therapy. A study that considered samples from more than 5000 tumors from the cancer genome atlas (TCGA) project, demonstrated that, while approximately the same number of protein coding and lncRNA genes were dysregulated, $60 \%$ of lncRNAs showed specificity for only one tumor type [146].

In addition, somatic copy number alterations (SCNA) found in cancer tissue often include lncRNA loci [57, 146, 147]. For example, the IncRNA $F A L 1$, a lncRNA that was found amplified in a number of different tumor types, was shown to be important for the tumorigenic effects of different cell lines via a BMI1-mediated mechanism (see above), and its expression level and copy number significantly correlated with patient survival [57]. Furthermore, several lncRNAs have been shown to be prognostic for overall or disease-free survival of patients [67, 82, 148-150], information that is integrated into therapeutic decisions. Depletion of selected lncRNAs led to reduced malignancy, assayed as tumor size or metastatic potential in xenograft experiments $[67,72,82$, $101,148,149,151-154]$, although these experiments were not able to distinguish between effects on tumor formation versus tumor progression. Further refinement was achieved when RNA knockdown was induced after tumor formation, mimicking therapeutic conditions. Reduced tumor growth was, for instance, observed upon FAL1 depletion [57]. In a different study, the inhibition of MALATI after tumor induction reduced metastasis formation in a xenograft lung cancer model and in a metastasizing breast cancer model [149, 155]. MALATl knockout mice do not show overt phenotypes $[110,156,157]$ suggesting that down-regulation of MALAT1 in humans might also not be harmful for normal human cells, which makes it an attractive target for systemic application in patients.

A special case is the noncoding pseudo gene BRAFPl, which has been shown to be either mutated or aberrantly expressed in cancers, like its coding homologue $B R A F$. A mouse model revealed that induced overexpression of Braf-rsl (the murine homologue of BRAFPl) leads to DLBCL (diffuse large $B$ cell lymphomas)-like tumors. However, when the transgene was first induced to form tumors and then shut down again, the tumors regressed demonstrating the functional significance of the pseudo gene [158]. Braf-rsl was shown to cause upregulation of Braf by acting as a ceRNA (competing endogenous RNA) and by "sponging" miRNAs that would otherwise target Braf transcripts.

One mechanism that cells can employ to prevent tumor formation is oncogene-induced senescence (OIS) [159]. The INK4B-ARF-INK4A locus, which plays a major role in OIS, is silenced in proliferating cells by Polycomb group proteins. This mechanism is dependent on the IncRNA 
ANRIL, which is transcribed from within the locus and acts in cis [58, 59, 160]. Furthermore, the MIR31HG gene located $400 \mathrm{~kb}$ upstream of the INK $4 B-A R F-I N K 4 A$ locus, also encodes a lncRNA involved in the regulation of INK4A [161]. A third lncRNA functioning in OIS, UCA1, stabilizes mRNAs of protein-coding genes involved in the senescence pathway, probably by sequestering hnRNPKA1 [162]. Also, the tumor suppressor p53 and its associated signaling pathways include lncRNAs. p53 binds and regulates numerous lncRNAs, such as the linc-p21, which in turn regulates gene expression in concert with p53 and p21 [163-166].

\section{Cardiovascular diseases}

LncRNAs have also been linked to cardiovascular diseases (CVD), which are a major cause of death in western societies, and have been studied both in patient data, as well as in mouse models. It was observed that several genomic regions significantly associated with myocardial infarction encode lncRNAs, for example MIAT and ANRIL $[167,168]$. Deletion of a $70 \mathrm{~kb}$ region including a large proportion of the ANRIL locus led to increased mortality in mice, particularly in combination with a high fat diet [169].

In other studies, massive parallel RNA sequencing revealed numerous lncRNAs displaying altered expression following surgically-induced myocardial infarction in mice $[170,171]$. In cellular differentiation models, the depletion of selected lncRNAs impaired cardiomyocyte formation making them promising candidates for in vivo assessment of their functions [172]. Analysis of the noncoding transcripts originating from the myosin heavy chain 7 (Myh7) locus, an important structural protein required for heart contractions, revealed that one, the lncRNA Mhrt, was down-regulated after induced myocardial infarction. Ectopic expression of Mhrt in mice, which had been subjected to this operation reduced the severity of symptoms observed in control mice during recovery [68]. When lncRNAs in plasma from myocardial infarction patients were profiled, a mitochondrial lncRNA named long intergenic noncoding RNA predicting cardiac remodeling $(L I P C A R)$ was found to significantly correlate with mortality caused by CVD and could thus be considered as a biomarker [173]. Whether this lncRNA also plays a causative role in infarction or heart failure remains to be investigated.

LncRNAs have been widely suggested as biomarkers and therapeutic targets in certain pathological settings. One reason for this is the extremely specific expression of many lncRNAs, opening the potential of targeting cellular subgroups rather than affecting patients systemically as in conventional treatments. Even if a lncRNA itself is not the disease driver, it can serve as drug target in cases where it acts as co-factor for a driver gene, which is more broadly expressed. Also, since lncRNAs often play quantitative roles rather than acting as switches in genetic programs, side effects of therapeutic treatments might be easier to control.

\section{Concluding remarks}

In recent years, the analysis of lncRNAs has highlighted the large diversity of cellular functions involving RNA molecules and has greatly expanded the catalog of functions previously attributed to noncoding RNAs. By now, we can conclude that noncoding RNAs play roles at all levels of gene control, including epigenetic mechanisms and nuclear organization, as well as in RNA processing, stability and translation. The recent discoveries of lncRNA functions provide good reasons for the notion that further investigation of lncRNAs bears high chances for the discovery of novel gene regulatory mechanisms in the future.

So far, only few lncRNAs playing an essential role in embryonic development, organogenesis or tissue homeostasis have been reported. Studies based on in vitro differentiation systems can provide important insights into the molecular modes of lncRNA function in local gene control or in regulatory networks. However, with regard to the roles of lncRNAs, for example in lineage decisions and cellular differentiation many findings are hampered by the lack of definitive proof in vivo. In particular, data derived from in vitro differentiated stem cells, whose genomic integrity and quality is hard to control, have to be interpreted cautiously. Also, the type of genetic change introduced into a lncRNA gene/locus for functional analysis (transcription stop, knockin, deletion etc.) needs to be considered carefully in order to draw the right conclusions [174-176]. Since lncRNAs do not only act as transcripts in cis or trans, but can also be side products of transcription affecting the expression of overlapping genes or accommodate regulatory DNA elements in their genomic loci, the analysis of their exact mode of action and functional roles in development and disease processes is more complex and difficult than that of proteincoding genes. It is now up to the responsibility of journal editors and reviewers to enforce the high standards of investigation this new and exciting field of research deserves.

Acknowledgments We thank Arica M Beisaw, Jesse Veenvliet, and Pavel Tsaytler for valuable comments on the manuscript. The authors' work is funded by the Max Planck Society (B.G.H.; S.U.S) and the DFG (German Research Foundation) Excellence Cluster CardioPulmonary System (Exc147-2) (P.G.). 
Open Access This article is distributed under the terms of the Creative Commons Attribution 4.0 International License (http:// creativecommons.org/licenses/by/4.0/), which permits unrestricted use, distribution, and reproduction in any medium, provided you give appropriate credit to the original author(s) and the source, provide a link to the Creative Commons license, and indicate if changes were made.

\section{References}

1. Okazaki Y, Furuno M, Kasukawa T et al (2002) Analysis of the mouse transcriptome based on functional annotation of 60,770 full-length cDNAs. Nature 420:563-573. doi:10.1038/ nature 01266

2. Djebali S, Davis CA, Merkel A et al (2012) Landscape of transcription in human cells. Nature 489:101-108. doi:10.1038/ nature 11233

3. Derrien T, Johnson R, Bussotti G et al (2012) The GENCODE v7 catalog of human long noncoding RNAs: analysis of their gene structure, evolution, and expression. Genome Res 22:1775-1789. doi:10.1101/gr.132159.111

4. Cabili MN, Trapnell C, Goff L et al (2011) Integrative annotation of human large intergenic noncoding RNAs reveals global properties and specific subclasses. Genes Dev 25:1915-1927. doi:10.1101/gad.17446611

5. Guo X, Gao L, Wang Y et al (2015) Advances in long noncoding RNAs: identification, structure prediction and function annotation. Brief Funct Genomics. doi:10.1093/bfgp/elv022

6. Harrow J, Frankish A, Gonzalez JM et al (2012) GENCODE: the reference human genome annotation for The ENCODE Project. Genome Res 22:1760-1774. doi:10.1101/gr.135350.111

7. Ingolia NT, Lareau LF, Weissman JS (2011) Ribosome profiling of mouse embryonic stem cells reveals the complexity and dynamics of mammalian proteomes. Cell 147:789-802. doi:10. 1016/j.cell.2011.10.002

8. Ruiz-Orera J, Messeguer X, Subirana JA, Alba MM (2014) Long non-coding RNAs as a source of new peptides. elife 3:e03523. doi:10.7554/eLife.03523

9. Guttman M, Russell P, Ingolia NT et al (2013) Ribosome profiling provides evidence that large noncoding RNAs do not encode proteins. Cell 154:240-251. doi:10.1016/j.cell.2013.06. 009

10. Bánfai B, Jia H, Khatun J et al (2012) Long noncoding RNAs are rarely translated in two human cell lines. Genome Res 22:1646-1657. doi:10.1101/gr.134767.111

11. Bazzini AA, Johnstone TG, Christiano R et al (2014) Identification of small ORFs in vertebrates using ribosome footprinting and evolutionary conservation. EMBO J. doi:10.1002/embj. 201488411

12. Frith MC, Forrest AR, Nourbakhsh E et al (2006) The abundance of short proteins in the mammalian proteome. PLoS Genet 2:e52. doi:10.1371/journal.pgen.0020052

13. Anderson DM, Anderson KM, Chang C-L et al (2015) A micropeptide encoded by a putative long noncoding RNA regulates muscle performance. Cell 160:595-606. doi:10.1016/j. cell.2015.01.009

14. Pauli A, Norris ML, Valen E et al (2014) Toddler: an embryonic signal that promotes cell movement via Apelin receptors. Science 343:1248636. doi:10.1126/science. 1248636

15. Yan Y, Cooper C, Hamedani MK et al (2015) The steroid receptor RNA activator protein (SRAP) controls cancer cell migration/motility. FEBS Lett 589:4010-4018. doi:10.1016/j. febslet.2015.11.007
16. Rupaimoole R, Lee J, Haemmerle M et al (2015) Long noncoding RNA ceruloplasmin promotes cancer growth by altering glycolysis. Cell Rep 13:2395-2402. doi:10.1016/j.celrep.2015. 11.047

17. Novikova IV, Hennelly SP, Tung C-S, Sanbonmatsu KY (2013) Rise of the RNA machines: exploring the structure of long noncoding RNAs. J Mol Biol 425:3731-3746. doi:10.1016/j.jmb. 2013.02.030

18. Weeks KM (2015) Review toward all RNA structures, concisely. Biopolymers 103:438-448. doi:10.1002/bip.22601

19. Smola MJ, Rice GM, Busan S et al (2015) Selective 2'-hydroxyl acylation analyzed by primer extension and mutational profiling (SHAPE-MaP) for direct, versatile and accurate RNA structure analysis. Nat Protoc 10:1643-1669. doi:10.1038/nprot.2015.103

20. Spitale RC, Flynn RA, Zhang QC et al (2015) Structural imprints in vivo decode RNA regulatory mechanisms. Nature. doi:10.1038/nature14263

21. Guttman M, Amit I, Garber M et al (2009) Chromatin signature reveals over a thousand highly conserved large non-coding RNAs in mammals. Nature 458:223-227. doi:10.1038/ nature 07672

22. Sun M, Gadad SS, Kim D-S, Kraus WL (2015) Discovery, annotation, and functional analysis of long noncoding RNAs controlling Cell-cycle gene expression and proliferation in breast cancer cells. Mol Cell. doi:10.1016/j.molcel.2015.06.023

23. Marques AC, Hughes J, Graham B et al (2013) Chromatin signatures at transcriptional start sites separate two equally populated yet distinct classes of intergenic long noncoding RNAs. Genome Biol 14:R131. doi:10.1186/gb-2013-14-11-r131

24. ENCODE Project Consortium (2012) An integrated encyclopedia of DNA elements in the human genome. Nature 489:57-74. doi:10.1038/nature11247

25. Iyer MK, Niknafs YS, Malik R et al (2015) The landscape of long noncoding RNAs in the human transcriptome. Nat Genet 47:199-208. doi:10.1038/ng.3192

26. Hansen TB, Jensen TI, Clausen BH et al (2013) Natural RNA circles function as efficient microRNA sponges. Nature 495:384-388. doi:10.1038/nature11993

27. Memczak S, Jens M, Elefsinioti A et al (2013) Circular RNAs are a large class of animal RNAs with regulatory potency. Nature 495:333-338. doi:10.1038/nature11928

28. Werner MS, Ruthenburg AJ (2015) Nuclear fractionation reveals thousands of chromatin-tethered noncoding RNAs adjacent to active genes. Cell Rep 12:1089-1098. doi:10.1016/j. celrep.2015.07.033

29. Herman RC, Williams JG, Penman S (1976) Message and nonmessage sequences adjacent to poly(A) in steady state heterogeneous nuclear RNA of HeLa cells. Cell 7:429-437

30. Yue F, Cheng Y, Breschi A et al (2014) A comparative encyclopedia of DNA elements in the mouse genome. Nature 515:355-364. doi:10.1038/nature13992

31. Haerty W, Ponting CP (2015) Unexpected selection to retain high GC content and splicing enhancers within exons of multiexonic lncRNA loci. RNA 21:333-346. doi:10.1261/rna.047324.114

32. Nitsche A, Rose D, Fasold M et al (2015) Comparison of splice sites reveals that long noncoding RNAs are evolutionarily well conserved. RNA 21:801-812. doi:10.1261/rna.046342.114

33. Ulitsky I, Shkumatava A, Jan CH et al (2011) Conserved function of lincRNAs in vertebrate embryonic development despite rapid sequence evolution. Cell 147:1537-1550. doi:10. 1016/j.cell.2011.11.055

34. Necsulea A, Soumillon M, Warnefors M et al (2014) The evolution of lncRNA repertoires and expression patterns in tetrapods. Nature 505:635-640. doi:10.1038/nature12943 
35. Diederichs S (2014) The four dimensions of noncoding RNA conservation. Trends Genet 30:121-123. doi:10.1016/j.tig.2014. 01.004

36. Mercer TR, Dinger ME, Sunkin SM et al (2008) Specific expression of long noncoding RNAs in the mouse brain. Proc Natl Acad Sci USA 105:716-721. doi:10.1073/pnas. 0706729105

37. Goff LA, Groff AF, Sauvageau M et al (2015) Spatiotemporal expression and transcriptional perturbations by long noncoding RNAs in the mouse brain. Proc Natl Acad Sci USA 112:6855-6862. doi:10.1073/pnas.1411263112

38. Grote P, Herrmann BG (2015) Long noncoding RNAs in organogenesis: making the difference. Trends Genet 31:329-335. doi:10.1016/j.tig.2015.02.002

39. Plath K, Fang J, Mlynarczyk-Evans SK et al (2003) Role of histone $\mathrm{H} 3$ lysine 27 methylation in $\mathrm{X}$ inactivation. Science 300:131-135. doi:10.1126/science.1084274

40. da Rocha ST, Boeva V, Escamilla-Del-Arenal M et al (2014) Jarid2 Is implicated in the initial Xist-induced targeting of PRC2 to the inactive X chromosome. Mol Cell 53:301-316. doi:10. 1016/j.molcel.2014.01.002

41. Zhao J, Sun BK, Erwin JA et al (2008) Polycomb proteins targeted by a short repeat RNA to the mouse X chromosome. Science 322:750-756. doi:10.1126/science.1163045

42. Rinn JL, Kertesz M, Wang JK et al (2007) Functional demarcation of active and silent chromatin domains in human HOX loci by noncoding RNAs. Cell 129:1311-1323. doi:10.1016/j. cell.2007.05.022

43. Li L, Liu B, Wapinski OL et al (2013) Targeted disruption of Hotair leads to homeotic transformation and gene derepression. Cell Rep 5:3-12. doi:10.1016/j.celrep.2013.09.003

44. Schorderet P, Duboule D (2011) Structural and functional differences in the long non-coding RNA hotair in mouse and human. PLoS Genet 7:e1002071. doi:10.1371/journal.pgen. 1002071

45. Klattenhoff CA, Scheuermann JC, Surface LE et al (2013) Braveheart, a long noncoding RNA required for cardiovascular lineage commitment. Cell 152:570-583. doi:10.1016/j.cell. 2013.01.003

46. Grote P, Herrmann BG (2013) The long non-coding RNA Fendrr links epigenetic control mechanisms to gene regulatory networks in mammalian embryogenesis. RNA Biol 10:1579-1585. doi:10.4161/rna.26165

47. Grote P, Wittler L, Hendrix D et al (2013) The tissue-specific lncRNA Fendrr is an essential regulator of heart and body wall development in the mouse. Dev Cell 24:206-214. doi:10.1016/j. devcel.2012.12.012

48. Marín-Béjar O, Marchese FP, Athie A et al (2013) Pint lincRNA connects the p53 pathway with epigenetic silencing by the Polycomb repressive complex 2. Genome Biol 14:R104. doi:10. 1186/gb-2013-14-9-r104

49. Brockdorff N (2013) Noncoding RNA and Polycomb recruitment. RNA 19:429-442. doi:10.1261/rna.037598.112

50. Khalil AM, Guttman M, Huarte M et al (2009) Many human large intergenic noncoding RNAs associate with chromatinmodifying complexes and affect gene expression. Proc Natl Acad Sci USA 106:11667-11672. doi:10.1073/pnas. 0904715106

51. Guttman M, Donaghey J, Carey BW et al (2011) lincRNAs act in the circuitry controlling pluripotency and differentiation. Nature 477:295-300. doi:10.1038/nature10398

52. Zhao J, Ohsumi TK, Kung JT et al (2010) Genome-wide identification of polycomb-associated RNAs by RIP-seq. Mol Cell 40:939-953. doi:10.1016/j.molcel.2010.12.011

53. Schmitz K-M, Mayer C, Postepska A, Grummt I (2010) Interaction of noncoding RNA with the rDNA promoter mediates recruitment of DNMT3b and silencing of rRNA genes. Genes Dev 24:2264-2269. doi:10.1101/gad.590910

54. O'Leary VB, Ovsepian SV, Carrascosa LG et al (2015) PARTICLE, a triplex-forming long ncRNA, regulates locus-specific methylation in response to low-dose irradiation. Cell Rep 11:474-485. doi:10.1016/j.celrep.2015.03.043

55. Mondal T, Subhash S, Vaid R et al (2015) MEG3 long noncoding RNA regulates the TGF- $\beta$ pathway genes through formation of RNA-DNA triplex structures. Nat Comms 6:7743. doi:10.1038/ncomms 8743

56. Batista PJ, Chang HY (2013) Long noncoding RNAs: cellular address codes in development and disease. Cell 152:1298-1307. doi:10.1016/j.cell.2013.02.012

57. Hu X, Feng Y, Zhang D et al (2014) A functional genomic approach identifies FAL1 as an oncogenic long noncoding RNA that associates with BMI1 and represses p21 expression in cancer. Cancer Cell 26:344-357. doi:10.1016/j.ccr.2014.07.009

58. Pasmant E, Laurendeau I, Héron D et al (2007) Characterization of a germ-line deletion, including the entire INK4/ARF locus, in a melanoma-neural system tumor family: identification of ANRIL, an antisense noncoding RNA whose expression coclusters with ARF. Cancer Res 67:3963-3969. doi:10.1158/ 0008-5472.CAN-06-2004

59. Yap KL, Li S, Muñoz-Cabello AM et al (2010) Molecular interplay of the noncoding RNA ANRIL and methylated histone $\mathrm{H} 3$ lysine 27 by polycomb CBX7 in transcriptional silencing of INK4a. Mol Cell 38:662-674. doi:10.1016/j.molcel.2010.03.021

60. Trievel RC, Shilatifard A (2009) WDR5, a complexed protein. Nat Struct Mol Biol 16:678-680. doi:10.1038/nsmb0709-678

61. Yang YW, Flynn RA, Chen Y et al (2014) Essential role of lncRNA binding for WDR5 maintenance of active chromatin and embryonic stem cell pluripotency. elife 3:e02046. doi:10. 7554/eLife.02046

62. Wang KC, Yang YW, Liu B et al (2011) A long noncoding RNA maintains active chromatin to coordinate homeotic gene expression. Nature 472:120-124. doi:10.1038/ nature 09819

63. Gomez JA, Wapinski OL, Yang YW et al (2013) The NeST long ncRNA controls microbial susceptibility and epigenetic activation of the interferon- $\gamma$ locus. Cell 152:743-754. doi:10.1016/j. cell.2013.01.015

64. Di Ruscio A, Ebralidze AK, Benoukraf T et al (2013) DNMT1interacting RNAs block gene-specific DNA methylation. Nature 503:371-376. doi:10.1038/nature 12598

65. Arab K, Park YJ, Lindroth AM et al (2014) Long noncoding RNA TARID directs demethylation and activation of the tumor suppressor TCF21 via GADD45A. Mol Cell. doi:10.1016/j. molcel.2014.06.031

66. Hamazaki N, Uesaka M, Nakashima K et al (2015) Gene activation-associated long noncoding RNAs function in mouse preimplantation development. Development 142:910-920. doi:10.1242/dev.116996

67. Prensner JR, Iyer MK, Sahu A et al (2013) The long noncoding RNA SChLAP1 promotes aggressive prostate cancer and antagonizes the SWI/SNF complex. Nat Genet 45:1392-1398. doi:10.1038/ng.2771

68. Han P, Li W, Lin C-H et al (2014) A long noncoding RNA protects the heart from pathological hypertrophy. Nature 514:102-106. doi:10.1038/nature13596

69. Bond AM, Vangompel MJW, Sametsky EA et al (2009) Balanced gene regulation by an embryonic brain ncRNA is critical for adult hippocampal GABA circuitry. Nat Neurosci 12:1020-1027. doi:10.1038/nn.2371

70. Cajigas I, Leib DE, Cochrane J et al (2015) Evf2 lncRNA/ BRG1/DLX1 interactions reveal RNA-dependent chromatin 
remodeling inhibition. Development 142:2641-2652. doi:10. 1242/dev. 126318

71. Minajigi A, Froberg JE, Wei C et al (2015) A comprehensive Xist interactome reveals cohesin repulsion and an RNA-directed chromosome conformation. Science 349:aab2276. doi:10.1126/ science.aab2276

72. Wang Y, He L, Du Y et al (2015) The long noncoding RNA lncTCF7 promotes self-renewal of human liver cancer stem cells through activation of Wnt signaling. Cell Stem Cell 16:413-425. doi:10.1016/j.stem.2015.03.003

73. Kaneko S, Bonasio R, Saldaña-Meyer R et al (2013) Interactions between JARID2 and noncoding RNAs regulate PRC2 recruitment to chromatin. Mol Cell. doi:10.1016/j.molcel.2013.11.012

74. Merry CR, Forrest ME, Sabers JN et al (2015) DNMT1-associated long non-coding RNAs regulate global gene expression and DNA methylation in colon cancer. Hum Mol Genet. doi:10. 1093/hmg/ddv343

75. Davidovich C, Wang X, Cifuentes-Rojas C et al (2015) Toward a Consensus on the Binding Specificity and Promiscuity of PRC2 for RNA. Mol Cell. doi:10.1016/j.molcel.2014.12.017

76. Jiang W, Liu Y, Liu R et al (2015) The lncRNA DEANR1 facilitates human endoderm differentiation by activating FOXA2 expression. Cell Rep 11:137-148. doi:10.1016/j.celrep. 2015.03.008

77. Kurian L, Aguirre A, Sancho-Martinez I et al (2015) Identification of novel long noncoding RNAs underlying vertebrate cardiovascular development. Circulation 131:1278-1290. doi:10.1161/CIRCULATIONAHA.114.013303

78. Ng S-Y, Bogu GK, Soh BS, Stanton LW (2013) The long noncoding RNA RMST interacts with SOX2 to regulate neurogenesis. Mol Cell 51:349-359. doi:10.1016/j.molcel.2013.07. 017

79. Rapicavoli NA, Qu K, Zhang J et al (2013) A mammalian pseudogene lncRNA at the interface of inflammation and antiinflammatory therapeutics. elife 2:e00762. doi:10.7554/eLife. 00762

80. Krawczyk M, Emerson BM (2014) p50-associated COX-2 extragenic RNA (PACER) activates COX-2 gene expression by occluding repressive NF- $\kappa B$ complexes. elife 3:e01776

81. Wang P, Xue Y, Han Y et al (2014) The STAT3-binding long noncoding RNA lnc-DC controls human dendritic cell differentiation. Science 344:310-313. doi:10.1126/science. 1251456

82. Xing Z, Lin A, Li C et al (2014) lncRNA directs cooperative epigenetic regulation downstream of chemokine signals. Cell 159:1110-1125. doi:10.1016/j.cell.2014.10.013

83. Kung JT, Kesner B, An JY et al (2015) Locus-specific targeting to the $\mathrm{X}$ chromosome revealed by the RNA interactome of CTCF. Mol Cell. doi:10.1016/j.molcel.2014.12.006

84. Sun S, Del Rosario BC, Szanto A et al (2013) Jpx RNA activates Xist by evicting CTCF. Cell 153:1537-1551. doi:10.1016/j.cell. 2013.05.028

85. Kim T-K, Hemberg M, Gray JM et al (2010) Widespread transcription at neuronal activity-regulated enhancers. Nature 465:182-187. doi:10.1038/nature09033

86. Koch F, Fenouil R, Gut M et al (2011) Transcription initiation platforms and GTF recruitment at tissue-specific enhancers and promoters. Nat Struct Mol Biol 18:956-963. doi:10.1038/nsmb. 2085

87. Natoli G, Andrau J-C (2012) Noncoding transcription at enhancers: general principles and functional models. Annu Rev Genet 46:1-19. doi:10.1146/annurev-genet-110711-155459

88. Collis P, Antoniou M, Grosveld F (1990) Definition of the minimal requirements within the human beta-globin gene and the dominant control region for high level expression. EMBO J 9:233-240
89. Ashe HL, Monks J, Wijgerde M et al (1997) Intergenic transcription and transinduction of the human beta-globin locus. Genes Dev 11:2494-2509

90. Orom UA, Shiekhattar R (2011) Long non-coding RNAs and enhancers. Curr Opin Genet Dev 21:194-198. doi:10.1016/j.gde. 2011.01.020

91. Andersson R, Gebhard C, Miguel-Escalada I et al (2014) An atlas of active enhancers across human cell types and tissues. Nature 507:455-461. doi:10.1038/nature12787

92. Ounzain S, Pezzuto I, Micheletti R et al (2014) Functional importance of cardiac enhancer-associated noncoding RNAs in heart development and disease. J Mol Cell Cardiol 76:55-70. doi:10.1016/j.yjmcc.2014.08.009

93. Orom UA, Derrien T, Beringer M et al (2010) Long noncoding RNAs with enhancer-like function in human cells. Cell 143:46-58. doi:10.1016/j.cell.2010.09.001

94. Li W, Notani D, Ma Q et al (2013) Functional roles of enhancer RNAs for oestrogen-dependent transcriptional activation. Nature 498:516-520. doi:10.1038/nature 12210

95. Lai F, Orom UA, Cesaroni M et al (2013) Activating RNAs associate with Mediator to enhance chromatin architecture and transcription. Nature 494:497-501. doi:10.1038/nature11884

96. Schaukowitch K, Joo J-Y, Liu X et al (2014) Enhancer RNA facilitates NELF release from immediate early genes. Mol Cell 56:29-42. doi:10.1016/j.molcel.2014.08.023

97. Mousavi K, Zare H, Dell'orso S et al (2013) eRNAs promote transcription by establishing chromatin accessibility at defined genomic loci. Mol Cell 51:606-617. doi:10.1016/j.molcel.2013. 07.022

98. Yin Y, Yan P, Lu J et al (2015) Opposing roles for the lncRNA haunt and its genomic locus in regulating HOXA Gene activation during embryonic stem cell differentiation. Cell Stem Cell 16:504-516. doi:10.1016/j.stem.2015.03.007

99. Maamar H, Cabili MN, Rinn J, Raj A (2013) linc-HOXA1 is a noncoding RNA that represses Hoxal transcription in cis. Genes Dev 27:1260-1271. doi:10.1101/gad.217018.113

100. Welsh IC, Kwak H, Chen FL et al (2015) Chromatin architecture of the Pitx2 locus requires CTCF- and Pitx2-dependent asymmetry that mirrors embryonic gut laterality. Cell Rep. doi:10.1016/j.celrep.2015.08.075

101. Yang L, Lin C, Jin C et al (2013) lncRNA-dependent mechanisms of androgen-receptor-regulated gene activation programs. Nature 500:598-602. doi:10.1038/nature12451

102. Yang F, Deng X, Ma W et al (2015) The lncRNA Firre anchors the inactive $\mathrm{X}$ chromosome to the nucleolus by binding CTCF and maintains H3K27me3 methylation. Genome Biol 16:52. doi:10.1186/s13059-015-0618-0

103. Hacisuleyman E, Goff LA, Trapnell C et al (2014) Topological organization of multichromosomal regions by the long intergenic noncoding RNA Firre. Nat Struct Mol Biol 21:198-206. doi:10.1038/nsmb. 2764

104. Bergmann JH, Li J, Eckersley-Maslin MA et al (2015) Regulation of the ESC transcriptome by nuclear long non-coding RNAs. Genome Res 25:1336-1346. doi:10.1101/gr.189027.114

105. Ramos AD, Andersen RE, Liu SJ et al (2015) The long noncoding RNA Pnky regulates neuronal differentiation of embryonic and postnatal neural stem cells. Cell Stem Cell 16:439-447. doi:10.1016/j.stem.2015.02.007

106. Lin N, Chang K-Y, Li Z et al (2014) An evolutionarily conserved long noncoding RNA TUNA controls pluripotency and neural lineage commitment. Mol Cell 53:1005-1019. doi:10. 1016/j.molcel.2014.01.021

107. Aprea J, Prenninger S, Dori M et al (2013) Transcriptome sequencing during mouse brain development identifies long noncoding RNAs functionally involved in neurogenic commitment. EMBO J 32:3145-3160. doi:10.1038/emboj.2013.245 
108. Barry G, Briggs JA, Vanichkina DP et al (2014) The long noncoding RNA Gomafu is acutely regulated in response to neuronal activation and involved in schizophrenia-associated alternative splicing. Mol Psychiatry 19:486-494. doi:10.1038/ mp.2013.45

109. Tripathi V, Ellis JD, Shen Z et al (2010) The nuclear-retained noncoding RNA MALAT1 regulates alternative splicing by modulating SR splicing factor phosphorylation. Mol Cell 39:925-938. doi:10.1016/j.molcel.2010.08.011

110. Eißmann M, Gutschner T, Hämmerle M et al (2012) Loss of the abundant nuclear non-coding RNA MALAT1 is compatible with life and development. RNA Biol 9:1076-1087. doi:10.4161/rna. 21089

111. Lee S, Kopp F, Chang T-C et al (2015) Noncoding RNA NORAD regulates genomic stability by sequestering PUMILIO proteins. Cell. doi:10.1016/j.cell.2015.12.017

112. Chen CY, Sarnow P (1995) Initiation of protein synthesis by the eukaryotic translational apparatus on circular RNAs. Science 268:415-417. doi:10.1126/science.7536344

113. Yan L, Yang M, Guo H et al (2013) Single-cell RNA-Seq profiling of human preimplantation embryos and embryonic stem cells. Nat Struct Mol Biol 20:1131-1139. doi:10.1038/ nsmb. 2660

114. Brannan CI, Dees EC, Ingram RS, Tilghman SM (1990) The product of the H19 gene may function as an RNA. Mol Cell Biol $10: 28-36$

115. Bartolomei MS, Zemel S, Tilghman SM (1991) Parental imprinting of the mouse $\mathrm{H} 19$ gene. Nature 351:153-155. doi:10. 1038/351153a0

116. Leighton PA, Ingram RS, Eggenschwiler J et al (1995) Disruption of imprinting caused by deletion of the $\mathrm{H} 19$ gene region in mice. Nature 375:34-39. doi:10.1038/375034a0

117. Dey BK, Pfeifer K, Dutta A (2014) The H19 long noncoding RNA gives rise to microRNAs miR-675-3p and miR-675-5p to promote skeletal muscle differentiation and regeneration. Genes Dev 28:491-501. doi:10.1101/gad.234419.113

118. Latos PA, Pauler FM, Koerner MV et al (2012) Airn transcriptional overlap, but not its lncRNA products, induces imprinted Igf2r silencing. Science 338:1469-1472. doi:10.1126/ science. 1228110

119. Kanduri C (2016) Long noncoding RNAs: lessons from genomic imprinting. Biochim Biophys Acta 1859:102-111. doi:10.1016/ j.bbagrm.2015.05.006

120. Penny GD, Kay GF, Sheardown SA et al (1996) Requirement for Xist in X chromosome inactivation. Nature 379:131-137. doi:10.1038/379131a0

121. Marahrens Y, Panning B, Dausman J et al (1997) Xist-deficient mice are defective in dosage compensation but not spermatogenesis. Genes Dev 11:156-166

122. Zhou Y, Cheunsuchon P, Nakayama Y et al (2010) Activation of paternally expressed genes and perinatal death caused by deletion of the Gt12 gene. Development 137:2643-2652. doi:10. $1242 / \mathrm{dev} .045724$

123. Sauvageau M, Goff LA, Lodato S et al (2013) Multiple knockout mouse models reveal lincRNAs are required for life and brain development. elife 2:e01749. doi:10.7554/eLife.01749

124. Nakagawa S, Naganuma T, Shioi G, Hirose T (2011) Paraspeckles are subpopulation-specific nuclear bodies that are not essential in mice. J Cell Biol 193:31-39. doi:10.1083/jcb. 201011110

125. Oliver PL, Chodroff RA, Gosal A et al (2015) Disruption of Visc-2, a brain-expressed conserved long noncoding RNA, does not elicit an overt anatomical or behavioral phenotype. Cereb Cortex 25:3572-3585. doi:10.1093/cercor/bhu196
126. Li L, Chang HY (2014) Physiological roles of long noncoding RNAs: insight from knockout mice. Trends Cell Biol. doi:10. 1016/j.tcb.2014.06.003

127. Nakagawa S, Shimada M, Yanaka K et al (2014) The lncRNA Neat 1 is required for corpus luteum formation and the establishment of pregnancy in a subpopulation of mice. Development. doi:10.1242/dev.110544

128. Herriges MJ, Swarr DT, Morley MP et al (2014) Long noncoding RNAs are spatially correlated with transcription factors and regulate lung development. Genes Dev 28:1363-1379. doi:10.1101/gad.238782.114

129. Ng S-Y, Johnson R, Stanton LW (2012) Human long non-coding RNAs promote pluripotency and neuronal differentiation by association with chromatin modifiers and transcription factors. EMBO J 31:522-533. doi:10.1038/emboj.2011.459

130. Ramos AD, Diaz A, Nellore A et al (2013) Integration of genome-wide approaches identifies lncRNAs of adult neural stem cells and their progeny in vivo. Cell Stem Cell 12:616-628. doi:10.1016/j.stem.2013.03.003

131. Chalei V, Sansom SN, Kong L et al (2014) The long non-coding RNA Dali is an epigenetic regulator of neural differentiation. elife 3:e04530. doi:10.7554/eLife.04530

132. Chan AS, Thorner PS, Squire JA, Zielenska M (2002) Identification of a novel gene NCRMS on chromosome 12q21 with differential expression between rhabdomyosarcoma subtypes. Oncogene 21:3029-3037. doi:10.1038/sj.onc.1205460

133. Uhde CW, Vives J, Jaeger I, Li M (2010) Rmst is a novel marker for the mouse ventral mesencephalic floor plate and the anterior dorsal midline cells. PLoS One 5:e8641. doi:10.1371/journal. pone. 0008641

134. Wheeler E, Huang N, Bochukova EG et al (2013) Genome-wide SNP and CNV analysis identifies common and low-frequency variants associated with severe early-onset obesity. Nat Genet 45:513-517. doi:10.1038/ng.2607

135. Blackshaw S, Harpavat S, Trimarchi J et al (2004) Genomic analysis of mouse retinal development. PLoS Biol 2:E247. doi:10.1371/journal.pbio.0020247

136. Krol J, Krol I, Alvarez CPP et al (2015) A network comprising short and long noncoding RNAs and RNA helicase controls mouse retina architecture. Nat Comms 6:7305. doi:10.1038/ ncomms 8305

137. Rapicavoli NA, Poth EM, Blackshaw S (2010) The long noncoding RNA RNCR2 directs mouse retinal cell specification. BMC Dev Biol 10:49. doi:10.1186/1471-213X-10-49

138. Sone M, Hayashi T, Tarui $\mathrm{H}$ et al (2007) The mRNA-like noncoding RNA Gomafu constitutes a novel nuclear domain in a subset of neurons. J Cell Sci 120:2498-2506. doi:10.1242/jcs. 009357

139. Kretz M, Webster DE, Flockhart RJ et al (2012) Suppression of progenitor differentiation requires the long noncoding RNA ANCR. Genes Dev 26:338-343. doi:10.1101/gad.182121.111

140. Zhu L, Xu P-C (2013) Downregulated LncRNA-ANCR promotes osteoblast differentiation by targeting EZH2 and regulating Runx2 expression. Biochem Biophys Res Commun 432:612-617. doi:10.1016/j.bbrc.2013.02.036

141. Lopez-Pajares V, Qu K, Zhang J et al (2015) A LncRNAMAF:MAFB transcription factor network regulates epidermal differentiation. Dev Cell 32:693-706. doi:10.1016/j.devcel. 2015.01.028

142. Kretz M, Siprashvili Z, Chu C et al (2013) Control of somatic tissue differentiation by the long non-coding RNA TINCR. Nature 493:231-235. doi:10.1038/nature11661

143. Ji P, Diederichs S, Wang W et al (2003) MALAT-1, a novel noncoding RNA, and thymosin beta4 predict metastasis and survival in early-stage non-small cell lung cancer. Oncogene 22:8031-8041. doi:10.1038/sj.onc.1206928 
144. Srikantan V, Zou Z, Petrovics G et al (2000) PCGEM1, a prostate-specific gene, is overexpressed in prostate cancer. Proc Natl Acad Sci USA 97:12216-12221. doi:10.1073/pnas.97.22. 12216

145. Brunner AL, Beck AH, Edris B et al (2012) Transcriptional profiling of long non-coding RNAs and novel transcribed regions across a diverse panel of archived human cancers. Genome Biol 13:R75. doi:10.1186/gb-2012-13-8-r75

146. Yan X, Hu Z, Feng Y et al (2015) Comprehensive genomic characterization of long non-coding RNAs across human cancers. Cancer Cell 28:529-540. doi:10.1016/j.ccell.2015.09.006

147. Du Z, Fei T, Verhaak RGW et al (2013) Integrative genomic analyses reveal clinically relevant long noncoding RNAs in human cancer. Nat Struct Mol Biol 20:908-913. doi:10.1038/ nsmb. 2591

148. Pandey GK, Mitra S, Subhash S et al (2014) The risk-associated long noncoding RNA NBAT-1 controls neuroblastoma progression by regulating cell proliferation and neuronal differentiation. Cancer Cell 26:722-737. doi:10.1016/j.ccell. 2014.09.014

149. Gutschner T, Hämmerle M, Eißmann M et al (2013) The noncoding RNA MALAT1 is a critical regulator of the metastasis phenotype of lung cancer cells. Cancer Res 73:1180-1189. doi:10.1158/0008-5472.CAN-12-2850

150. Xue S, Li Q-W, Che J-P et al (2015) Decreased expression of long non-coding RNA NBAT-1 is associated with poor prognosis in patients with clear cell renal cell carcinoma. Int J Clin Exp Pathol 8:3765-3774

151. Trimarchi T, Bilal E, Ntziachristos P et al (2014) Genome-wide mapping and characterization of Notch-regulated long noncoding RNAs in acute leukemia. Cell 158:593-606. doi:10.1016/j. cell.2014.05.049

152. Gupta RA, Shah N, Wang KC et al (2010) Long non-coding RNA HOTAIR reprograms chromatin state to promote cancer metastasis. Nature 464:1071-1076. doi:10.1038/nature08975

153. Liu B, Sun L, Liu Q et al (2015) A cytoplasmic NF- $\kappa B$ interacting long noncoding RNA blocks I $\mathrm{B}$ phosphorylation and suppresses breast cancer metastasis. Cancer Cell 27:370-381. doi:10.1016/j.ccell.2015.02.004

154. Dijkstra JM, Alexander DB (2015) The "NF- $\kappa B$ interacting long noncoding RNA" (NKILA) transcript is antisense to cancerassociated gene PMEPA1. F1000Res 4:96. doi:10.12688/ f1000research.6400.1

155. Arun G, Diermeier S, Akerman M et al (2015) Differentiation of mammary tumors and reduction in metastasis upon Malat1 lncRNA loss. Genes Dev 30:34-51. doi:10.1101/gad.270959.115

156. Nakagawa S, Ip JY, Shioi G et al (2012) Malat1 is not an essential component of nuclear speckles in mice. RNA 18:1487-1499. doi:10.1261/rna.033217.112

157. Zhang B, Arun G, Mao YS et al (2012) The lncRNA Malat1 is dispensable for mouse development but its transcription plays a cis-regulatory role in the adult. Cell Rep 2:111-123. doi:10. 1016/j.celrep.2012.06.003

158. Karreth FA, Reschke M, Ruocco A et al (2015) The BRAF pseudogene functions as a competitive endogenous RNA and induces lymphoma in vivo. Cell. doi:10.1016/j.cell.2015.02.043

159. Gil J, Peters G (2006) Regulation of the INK4b-ARF-INK4a tumour suppressor locus: all for one or one for all. Nat Rev Mol Cell Biol 7:667-677. doi:10.1038/nrm1987

160. Wan G, Mathur R, Hu X et al (2013) Long non-coding RNA ANRIL (CDKN2B-AS) is induced by the ATM-E2F1 signaling pathway. Cell Signal 25:1086-1095. doi:10.1016/j.cellsig.2013. 02.006

161. Montes M, Nielsen MM, Maglieri G et al (2015) The lncRNA MIR31HG regulates p16(INK4A) expression to modulate senescence. Nat Comms 6:6967. doi:10.1038/ncomms7967
162. Kumar PP, Emechebe U, Smith R et al (2014) Coordinated control of senescence by lncRNA and a novel T-box3 co-repressor complex. elife. doi:10.7554/eLife.02805

163. Huarte M, Guttman M, Feldser D et al (2010) A large intergenic noncoding RNA induced by p53 mediates global gene repression in the p53 response. Cell 142:409-419. doi:10.1016/j.cell. 2010.06.040

164. Sánchez Y, Segura V, Marín-Béjar O et al (2014) Genome-wide analysis of the human p53 transcriptional network unveils a lncRNA tumour suppressor signature. Nat Comms 5:5812. doi:10.1038/ncomms6812

165. Dimitrova N, Zamudio JR, Jong RM et al (2014) LincRNA-p21 activates p 21 in cis to promote Polycomb target gene expression and to enforce the G1/S checkpoint. Mol Cell 54:777-790. doi:10.1016/j.molcel.2014.04.025

166. Wu G, Cai J, Han Y et al (2014) LincRNA-p21 regulates neointima formation, vascular smooth muscle cell proliferation, apoptosis, and atherosclerosis by enhancing p53 activity. Circulation 130:1452-1465. doi:10.1161/CIRCULATIONAHA. 114.011675

167. Ishii N, Ozaki K, Sato H et al (2006) Identification of a novel non-coding RNA, MIAT, that confers risk of myocardial infarction. J Hum Genet 51:1087-1099. doi:10.1007/s10038006-0070-9

168. Broadbent HM, Peden JF, Lorkowski S et al (2008) Susceptibility to coronary artery disease and diabetes is encoded by distinct, tightly linked SNPs in the ANRIL locus on chromosome 9p. Hum Mol Genet 17:806-814. doi:10.1093/hmg/ddm352

169. Visel A, Zhu Y, May D et al (2010) Targeted deletion of the 9 p21 non-coding coronary artery disease risk interval in mice. Nature 464:409-412. doi:10.1038/nature08801

170. Matkovich SJ, Edwards JR, Grossenheider TC et al (2014) Epigenetic coordination of embryonic heart transcription by dynamically regulated long noncoding RNAs. Proc Natl Acad Sci USA 111:12264-12269. doi:10.1073/pnas.1410622111

171. Ounzain S, Micheletti R, Beckmann T et al (2015) Genomewide profiling of the cardiac transcriptome after myocardial infarction identifies novel heart-specific long non-coding RNAs. Eur Heart J 36:353-368a. doi:10.1093/eurheartj/ehu180

172. Ounzain S, Micheletti R, Arnan C et al (2015) CARMEN, a human super enhancer-associated long noncoding RNA controlling cardiac specification, differentiation and homeostasis. J Mol Cell Cardiol. doi:10.1016/j.yjmcc.2015.09.016

173. Kumarswamy R, Bauters C, Volkmann I et al (2014) Circulating long noncoding RNA, LIPCAR, predicts survival in patients with heart failure. Circ Res 114:1569-1575. doi:10.1161/ CIRCRESAHA.114.303915

174. Bassett AR, Akhtar A, Barlow DP et al (2014) Considerations when investigating lncRNA function in vivo. elife 3:e03058

175. Janowski BA, Huffman KE, Schwartz JC et al (2005) Inhibiting gene expression at transcription start sites in chromosomal DNA with antigene RNAs. Nat Chem Biol 1:216-222. doi:10.1038/ nchembio725

176. Goff LA, Rinn JL (2015) Linking RNA biology to lncRNAs. Genome Res 25:1456-1465. doi:10.1101/gr.191122.115

177. Stadtfeld M, Apostolou E, Ferrari F, et al. (2012) Ascorbic acid prevents loss of Dlk1-Dio3 imprinting and facilitates generation of all-iPS cell mice from terminally differentiated B cells. Nat Genet 44:398-405, S1-S2. doi:10.1038/ng.1110

178. Zhang X, Lian Z, Padden C et al (2009) A myelopoiesis-associated regulatory intergenic noncoding RNA transcript within the human HOXA cluster. Blood 113:2526-2534. doi:10.1182/ blood-2008-06-162164

179. Delpretti S, Montavon T, Leleu M et al (2013) Multiple enhancers regulate Hoxd genes and the Hotdog LncRNA during cecum budding. Cell Rep. doi:10.1016/j.celrep.2013.09.002 
180. Gong C, Li Z, Ramanujan K et al (2015) A long non-coding RNA, LncMyoD, regulates skeletal muscle differentiation by blocking IMP2-mediated mRNA translation. Dev Cell 34:181-191. doi:10.1016/j.devcel.2015.05.009

181. Prensner JR, Sahu A, Iyer MK et al (2014) The IncRNAs PCGEM1 and PRNCR1 are not implicated in castration resistant prostate cancer. Oncotarget 5:1434-1438
182. McHugh CA, Chen C-K, Chow A et al (2015) The Xist lncRNA interacts directly with SHARP to silence transcription through HDAC3. Nature 521:232-236. doi:10.1038/nature14443

183. Kay GF, Penny GD, Patel D et al (1993) Expression of Xist during mouse development suggests a role in the initiation of $\mathrm{X}$ chromosome inactivation. Cell 72:171-182 